\author{
by \\ Akhilkumar Verma \\ i) \\ M.S. - Bombay University; India
}

A MASTER'S THESIS

submitted in partial fulfiliment of the

requirements for the degree

MASTER OF SCIENCE

Department of Chemistry

KANSAS STATE UNIVERSITY

Manhattan, Kansas

1984

Approved by:

Duy H. Htua

Major Propessor 
2

$\angle D$

2668

14

1984

.647

c. 2

4-Substituted 2-azetidinones can be obtained in excellent yields from the reactions of various cuprates with 4-acetoxy-2-azetidinone. When 4acetoxy-2-azetidinone was treated with one equivalent of the cuprates in ether: dimethylsulfide $(1: 1)$ at $-50^{\circ} \mathrm{C}$ to $-30^{\circ} \mathrm{C}$, only $20-30 \%$ of the corresponding 4-substituted 2-azetidinones were obtained. However when two equivalents of the cuprates were used, the yields were excellent (71-98\%). By this method we have been able to introduce alkyl, aryl, allyl and alkenyl groups at the 4-position of 2-azetidinones in excellent yields. 
IABLE OF CONTENTS

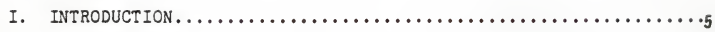

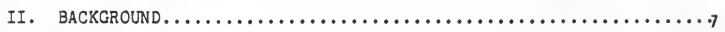

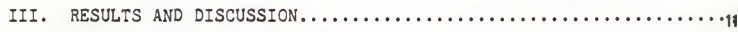

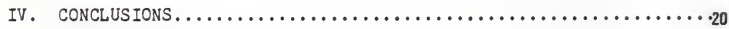

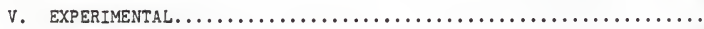

(1) Preparation of $4-\underline{n}$-butylazetidin-2-one( 8 ) $\ldots \ldots \ldots \ldots \ldots 21$

(2) Preparation of 4-sec-butylazetidin-2-one(9) $\ldots \ldots \ldots \ldots \ldots 23$

(3) Preparation of 4 -t-butylazetidin-2-one (10) $\ldots \ldots \ldots \ldots \ldots .24$

(4) a. Preparation of 1-t-butyldimethylsily loxy-3-

if thiopropane..........................

b. Preparation of 4-t-butyldimethylsilyloxy-

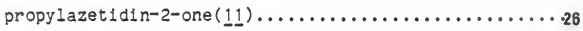

(5) a. Preparation of 2-(2-bromoethyl)-1,3-dioxolane.......27

b. Preparation of 3,3-ethylenedioxypropylmagnesium-

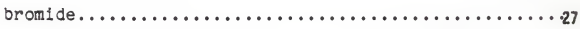

c. Preparation of 4-(3,3-ethylenedioxypropyl)-2-azetidin-

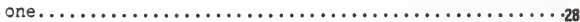

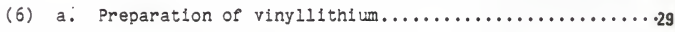

b. Standardization of vinylithium................

c. Preparation of 4 -vinylazetidin-2-one $(13) \ldots \ldots \ldots \ldots \ldots$

(7) a. Preparation of 1 -1ithiocyclohexene..............

b. Preparation of 4-cyclohex-1-ene-azetidin-2-one(14) $\cdots 31$

(8) Preparation of 4-phenylazetidin-2-one (15) $\ldots \ldots \ldots \ldots \ldots \ldots 3$

(9) a. Preparation of $1-11$ thionaphthalene.............. 34 
b. Preparation of 4-[1-naphthy $]$ azetidin-2-one $(16) \ldots \ldots 34$

(10) Preparation of 4-allylazetidin-2-one(17) .............36

(11) Preparation of racemic-4-[3-(4'-methyl phenylsulfiny 1)-2-

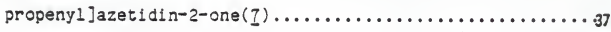

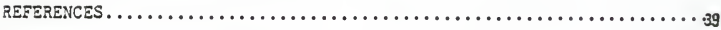

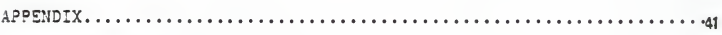

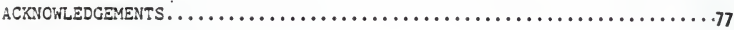




\section{INTRODUCTION}

The discovery of thienamycin (1), an unusually potent carbapenem antibiotic, has led to intense activity in the synthesis of 3 -lactam antibiotics. These substances possess a reactive 3 -lactam linkage, which show high antibacterial potency and a wide antibacterial spectrum. The $3-$ lactam linkage is also known to be present in penicillins $(2)^{2}$ and other related antibiotics.

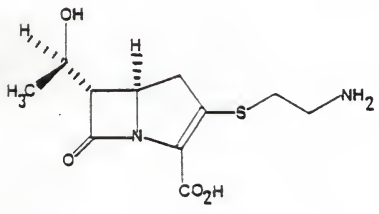

1

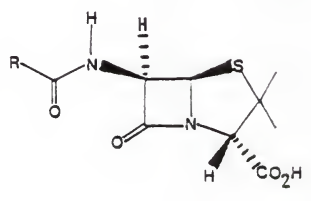

2

However, unlike the pentcillins which have a carbon-sulfur bond at $0-4$, the carbapenems have a carbon-carbon bond at the 4-position. Although the penicillins have been known for quite some time, the carbapenems have been extensively studted only in the last 10 years. The shemistry of carbapenems zained momentum in 1975, following the lsolation of thienamyctn from a Streptomyces species.

Thienamycin has unusually high potency against both gram-positive and gram-negative bacteria. Of particular interest is its activity against Pseudomonas spp. and its resistance to bacterial, s-lactamase ${ }^{3}$. 
The mode of action of these $\beta$-lactam antibiotics is still not clear. It has been proposed that a $\beta$-lactam antibiotic inhibits transpeptidase activity because it is a structural analogue of the D-alanyl-D-alanine portion of the nascent peptidoglycan $3^{6}$.

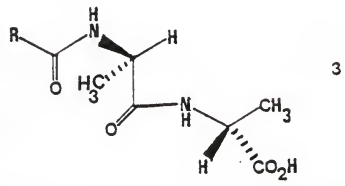

However, thienamycin lacks the $\beta$-amide functionality present in penicilins and other related antibiotics. Possibly the hydroxyl group in thienamycin can bind the same site normally bound by the s-amido group of other $\beta$-lactam antibiotics when complexing with the bacterial cell wall enzymes.

The most common methods for preparing penicillins and their derivatives are still by direct fermentation or by synthetic modification of fermentation derived starting materials. However, the low yields ${ }^{4}$ obtained for the carbapenems by fermentation processes have engendered intense interest in synthetic approaches to these biologically important compounds, particularly the construction of the unusual ring system. 
II. BACKGROUND

Since the discovery of thienamycin and other related carbapenem antiblotics, much attention has been focused on carbon-carbon bond formation at the 4-position of 2-azetidinones. The formation of a carbon-carbon bond at the C-4 position of a $\beta-1$ actam might be very useful in the synthesis of carbapenem type antiblotics. Although many 2-azetidinones bearlng carbon substituents at $\mathrm{C}-4$ are known, there have been few reports of carbon-carbon bond formation at $\mathrm{C}-4$. In all these reports either 4-phenylsulphony 1azetidin-2-one (5) or 4-acetoxyazetidin-2-one (6) have been used as starting materials ${ }^{5}$. Table I summarizes all the methods for carbon-carbon bond formation at $\mathrm{C}-4$ that have been reported so $\mathrm{far}$.

\section{TABLE-I}
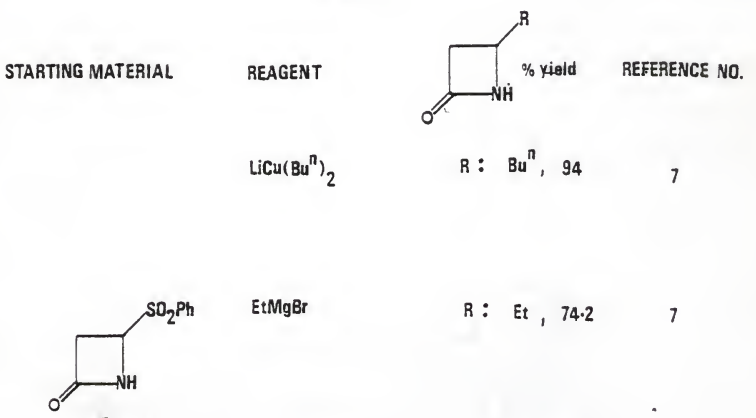

EtMgBr

R: Et , 74.2

7

5

$$
\begin{array}{lcl}
\mathrm{CH}_{2}=\mathrm{CHMgBr} & \mathrm{R}: \mathrm{CH}=\mathrm{CH}_{2}, 7 \\
\text { LiCu}\left(\mathrm{CH}_{2}-\mathrm{CH}=\mathrm{CH}_{2}\right)_{2} & \text { R : } \mathrm{CH}_{2} \mathrm{CH}=\mathrm{CH}_{2}, 7
\end{array}
$$


$\operatorname{LiCu}\left(\mathrm{Bu}^{\mathrm{n}}\right)_{2}$

EtMgBr

$\mathrm{CH}_{2}=\mathrm{CHMgBr}$

n-BuLi<smiles>CCOC(C#N)(OCC)c1ccccc1</smiles>

B: $B z$ of $t-B u$

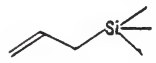

$B: B u^{n}, 89$

R: Et , $12 \cdot 4$

7

R: $\quad \mathrm{CH}=\mathrm{CH}_{2}, 3.5$

7

R: $8 u^{n}, 12$

8

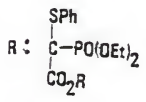

R: $8 z, 96$

R: $t-B u, 80$

R.: $\mathrm{CH}_{2}-\mathrm{CH} \mathrm{CH}_{2}, 63$

10

As seen from the table, only a few cases for carbon-carbon bond formation using 4-phenylsulphonylazetidin-2-one(ㅌ) as the starting waterial have been reported and in all cases the yields are reasonably good. This starting matertal 4-phenylsulphonylazetidin-2-one(ㅍ) has to be propared ercm

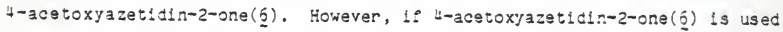


as

the starting material, the yields in many cases are low. We therefore investigated the possibility of improving the yield for carbon-carbon bond formation at the 4-position of $\beta$-lactam by using 4-acetoxyazetidin-2-one( 6 ) as the starting material.

Since we have been successful in our laboratory for obtaining good asymmetric induction in enones by reacting them with chiral allylsulfinyl anion, it was tempting for us to see whether $\beta$-lactam can be used as the substrate. A possible way to achieve this, is to react the azetidinone 6 with one equivalent of base and one equivalent of chiral allylsulfinyl anion as shown in equation 1 .
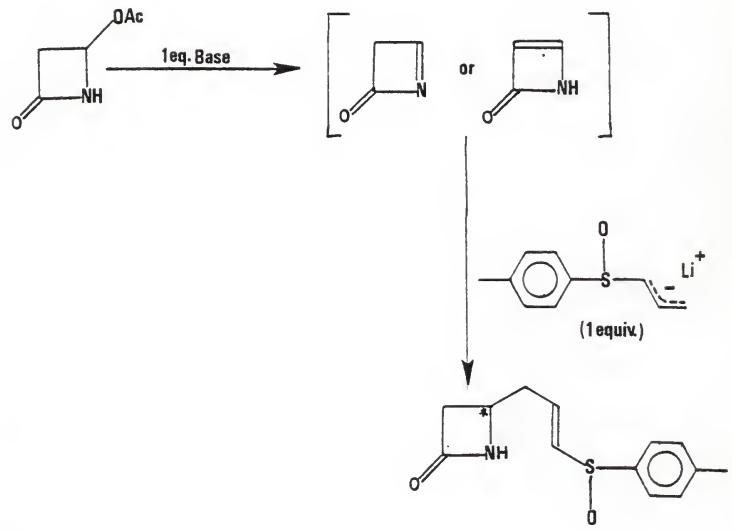
In a recent communication ${ }^{\prime \prime}$, the preparation of $3-1$ actam 4 a key intermediate in the asymmetric synthesis of $(+)$-thienamycin has been reported.

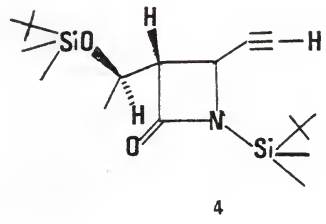

A key step in the synthesis of B-lactan 4 was the stereoselective phenylthiolation at the 4-position of either of the two starting materials 5 or 6 with thiophenol in benzene containing cinchonidine at $35^{\circ}$ for 62.5 hrs. The product (+)-4-phenylthioazetidin-2-one (18) was obtained in 96 and $79 \%$ yield and 54 and $38 \%$ optical purity respectively. 


\section{RESULTS AND DISCUSSION}

Before studying the reaction of azetidinone $\underline{6}$ with chiral allylsulfoxide, we decided to initially investigate the reaction of racemic allylsulfoxide with azetidinone $\underline{6}$.

When azetidinone 6 is allowed to react with one equivalent of 11 thium disopropylamide (LDA) in tetrahydrofuran (THF) at $-78^{\circ} \mathrm{C}$ and one equivalent of racemic allylsulfinyl anion [formed by treating one equivalent of racemic p-tolylallylsulfoxide with one equivalent of lithium disopropylamide in tetrahydrofuran $\left.\left(-78^{\circ} \mathrm{C}--30^{\circ} \mathrm{C}\right)\right]$, only a trace amount of the desired compound I was obtained.

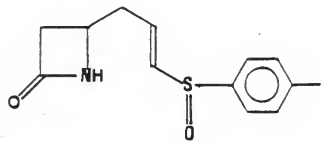

7

The NMR spectrum indicated the presence of unidentifiable polymer in major amount. However, when one equivalent of azetidinone $\underline{6}$ in tetrahydrofuran ($78^{\circ} \mathrm{C}$ ) is allowed to react directly with two equivalents of racemic allylsulfinyl anion in tetrahydrofuran $\left(-78^{\circ} \mathrm{C}--50^{\circ} \mathrm{C}\right)$, about $14 \%$ of the desired B-lactam I is obtained. Cyclization of the B-lactam I would give us a two step synthesis of the carbapenem skeleton. Further, if the azetidinone $\underline{6}$ was allowed to react with two equivalents of chiral p-tolyl allylsulfinyl anion, we would expect the resulting s-lactam to have a chiral center at the 4-position. This $\beta$-lactam can next be cyclized to give us a two step asymmetric synthesis of the carbapenem skeleton. As the yield of the $\hat{s}^{-}$ lactam 7 was low, our main objective was to develop a useful method for 
carbon-carbon bond formation at the 4 -position of azetidinone 6 and the subsequent cyclization to carbapenem which will serve as synthetic intermediate for the synthesis of thienamycin.

The important role of dimethylsulfide in cuprate reactions was realized while we were investigating the reaction between 1-t-butyldimethylsilyloxy2,2-dimethyl-3-propyl cuprate $(\underline{20})$ and $x, 3$-unsaturated sulfoxide 21 as part of another project (equation 2).

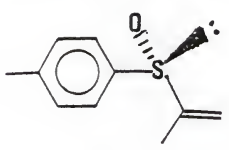

21

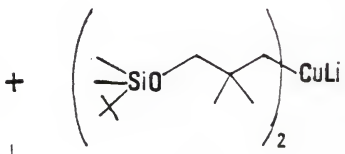

20

\section{Ether: MesMe}

$1: 1$

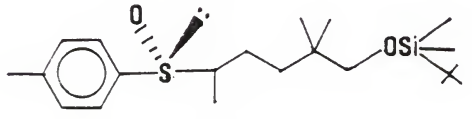

22

In ether alone the yield of the 1,4-adduct 22 was low but if echer : Mesile (1:1) was used as the solvent system, about $95 \%$ yield of the 1,4 -adduct $? ?$ was obtalned. Hence dimethylsulfide was playing an important role in cuprate reactions. The literature ${ }^{7}$ does mention a few examples in which $4-$ substituted azetidinones have been obtained by reacting azetidinone $\underline{z}$ on with alkylcuprates. However, in all these reports experimental details such as the solvent used have not been mentioned. This prompted us to investigate the possibility of obtaining L-substituted azetidtncnes, by 
reacting azetidinone 6 with various cuprates in ether : MeSMe $(1: 1)$ as the solvent system.

When azetidinone 6 was treated with one equivalent of the cuprates in ether: dimethylsulfide $(1: 1)$ at $-50^{\circ} \mathrm{C}--30^{\circ} \mathrm{C}$ only $20-30 \%$ yields of the corresponding 4-substituted-2-azetidinones were obtained (equation 3 ). However, if two equivalents of the cuprates were used, excellent yields ( 71 - 98\%) were achieved. The results are summarized in Table II.

TABLEI REACTIONS OF 4-ACETOXY-2-AZETIOINONE (1) NITH HOMOCUPRATES.

\begin{tabular}{|c|c|c|c|c|}
\hline \multirow{2}{*}{ ENTRY } & \multicolumn{2}{|c|}{$\mathrm{R}_{2} \mathrm{Cu}^{-} \mathrm{M}^{*}$} & & R : Isolates \\
\hline & $R$ & M & & $B=-$ \\
\hline 1 & $\mathrm{CH}_{3} \mathrm{CH}_{2} \mathrm{CH}_{2} \mathrm{CH}_{2}-$ & bi & 8 & $(94)$ \\
\hline 2 & $\begin{array}{c}\mathrm{CH}_{3} \\
\mathrm{CH}_{3} \mathrm{CH}_{2} \mathrm{CH}_{-}-\end{array}$ & ن & 9 & (96) \\
\hline 3 & $\begin{array}{r}\mathrm{CH}_{3} \\
\mathrm{CH}_{3}-\mathrm{C}- \\
\mathrm{CH}_{3}\end{array}$ & $\mathrm{Li}$ & 10 & $(\xi \hat{)})$ \\
\hline 4 & ${ }_{4} \mathrm{CH}_{2}-$ & L & 11 & $(§ \overline{8})$ \\
\hline 5 & & $\mathrm{MgBr}$ & 12 & $(92)$ \\
\hline 6 & $\mathrm{CH}-$ & Li & 13 & (75) \\
\hline 7 & & Li & 14 & $(\$ 5)$ \\
\hline 8 & & bi & 15 & $\langle 82\rangle$ \\
\hline 9 & & 4. & 16 & $8 C)$ \\
\hline 10 & $\mathrm{CH}_{2}=\mathrm{CHCH}_{2}-$ & bi & 17 & $\because:$ \\
\hline
\end{tabular}




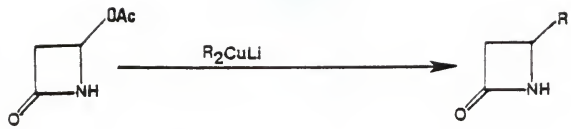

We have also investigated the possibility of obtaining carbapenem 23 from B-lactam 11. To achieve this, the 3 -lactam 11 was subjected to the sollowing sequence of reactions indicated below.
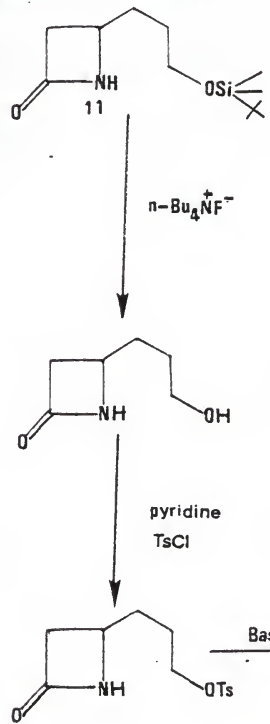

pyridine

$\mathrm{TsCl}$ 
The intramolecular cyclization step $(23 a-23)$ is being studied. This thesis will not cover the studies of the cyclization to carbapenem.

The structure of cuprates such as lithium dimethylouprate and 11thium dibutylcuprate has been investigated in ether as a solvent. ${ }^{12,13}$ There is much evidence to show that these cuprates possess a dimeric cyclic structure in ether.

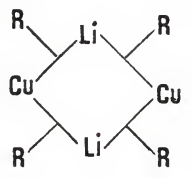

\section{$R$ : Me or Bu}

It is possible that other dialkylcuprates have a similar cyclic structure.

we are still not sure about the exact mechanism of these cuprate reactions. The mechanisms indicated below account for the improvement in yield caused by using two equivalents of cuprated. However, it is possible that the reaction is proceeding via an entirely different mechanism.

\section{Mechanisms}

(a) Since two equivalents of cuprate are required to improve the yield, it is possible that one equivalent of cuprate removes the acidic $\mathrm{N}$-i proton while the second equivalent of cuprate is utilized in displacing the acetate group before elimination takes place.

(b) In this mechanism also, the first equivalent of the cuprate is utilized in removing the acidic $\mathrm{N}-\mathrm{H}$ proton. However, this mechanism differs from mechanism ' $a$ ' in that elimination of the acetate group zakes place as soon as the $N-t$ proton is removed resulting in the cormation of unstable 
cyclic iminone 25. The second equivalent of cuprate now adds across the $\mathrm{C}=\mathrm{N}$ bond of the iminone.

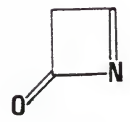

25

If one equivalent of cuprate is used, then af ter removing the acidic.. $\mathrm{N}-\mathrm{H}$ proton, enough cuprate is not avallable to undergo displacement or addition. Consequently the yield is also low.

(c) Although mechanisms (a) and (b) satisfactorily account for the experimental observation, the possibility that the two equivalents of cuprate complex with the nitrogen of the azetidinone 6 because of the strong affinity of copper for nitrogen cannot be ruled out. This could be followed by some internal displacement of the acetoxy gorup by alkyl group to give the desired B-1actam.

Neither ether nor tetrahydrofuran alone as the solvent in the reaction of 6 with cuprates gave appreciable amount of the desired product. However, the yields are found to improve considerably if ether and dimethylsulfide in 1:1 proportion is used as the solvent system. Therefore dimethylsulfide might be playing an important role in the displacement reaction.

Except for dialkylcuprate (entry 5) which was made from alkylmagnesium bromide and CuI.MeSMe (equation 4), the other cuprates were generated from their corresponding lithium salts as shown in equation 5 . 

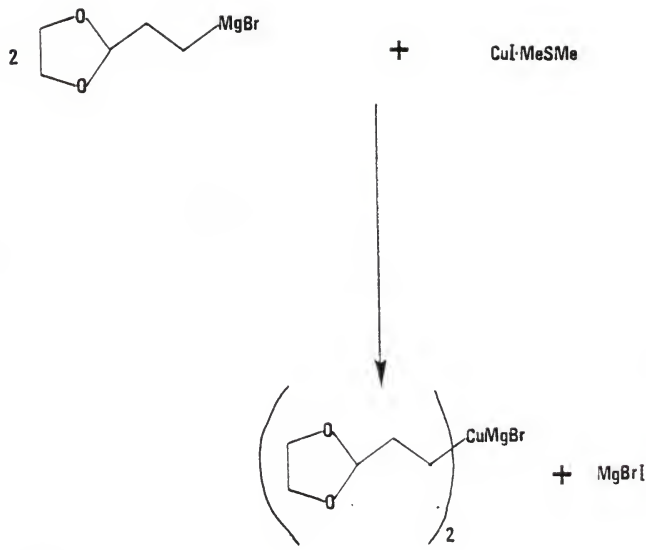

(4)

$2 \mathrm{RLI}+\mathrm{CUI} \cdot \mathrm{MeSMe} \longrightarrow \mathrm{R}_{2} \mathrm{CuLi}+\mathrm{LiI}$

Unlike the dialkylcuprate, divinylcuprate generated from vinylmagnesium bromide gave low yield of B-lactam 13. However, if divinylcuprate was generated from vinyllithium the yield of 13 improved considerably. Further if the vinylithium was prepared from tetravinyltin and phenyllithium (equation 6), ${ }^{14}$ then the divinylcuprate generated as shown in equation 5 did not give any product when reacted with azetidinone $\underline{\sigma}$. 

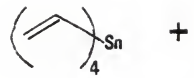

\section{PhLi}

4

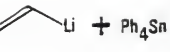

(6)

Although most of the byproduct tetraphenyltin was removed prior to the reaction with CuI.MeSMe, it is possiole that traces of tetraphenyltin remaining behind intereered in the reaction. Hence an alternative method ior the preparation of vinylitihium had to be sought. Vinyllithium was conveniently prepared in ether by allowing vinyloromide to react with 1.2 equivalents of t-butyllithium $(1.8 \mathrm{M})$. This vinyllithium was standardized by titration with diphenylacetic acid dissolved in tetrahydrofuran. The divinylcuprate generated from this standardized vinyllithium when allowed to react with azetidinone $\underline{6}$ gave 75 yield of the 3 -lactam 13 . The spectral data indicated the absence of 4-t-butylazetidin-2-one 10. Therefore all the t-butyllithium must have been used up in the preparation of vinylithium. Unlike vinylifthium which cannot be prepared from vinylchloride or oromide and ordinary lithium metal, ${ }^{15}$ i-lithiocyclohexene could be generated from 1bromocyclohexene and lithium metal. The cuprate generated from this 1Ithiocyclohexene when reacted with azetidinone 6 gave excelient yield of the s-lactan 14 (Entry 7). Although 2-(2-bromoethy 1)-1,3-dioxolane(19) reacted with magnesium metal in tetrahydrofuran to form the oriznard reagent ${ }^{16}$, it did not react with ordinary lithium metal. 


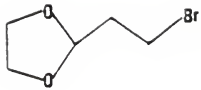

19

The dialkylcuprate was therefore generated from the corresponding Griznard reagent (Entry 5). This cuprate when allowed to react with azetidinone 6 Bave a 92\% yield of the desired 3-lactam 12 .

Since the yields of these cuprate reactions are excelient, it was tempting for us to see if we could improve the yield of $Z$ by treating azetidinone 6 with tiro equivalents of racemic p-tolylallyl sulfoxide cuprate. To form the cuprate, racemic putolylallyl sulfoxide (2 equivalents) in ether at $-78^{\circ} \mathrm{C}$ was treated with two equivalents of Iithium disopropylamide in ether at $-78^{\circ} \mathrm{C}$ and one equivalent of CuI.MeSile as shown in equation 7 .
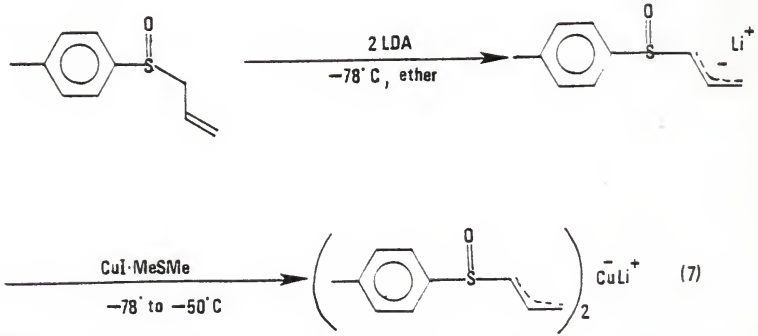

(7)

However, unidentifiable polymer resulted on reaction with azetidinone 5 . 
IV. CONCLUSION

Since the reaction of racemic p-tolylallylsulfoxide with azetidinone 6 did not give good yield, asymmetric induction at c-4 of azetidinone 6 using chiral p-tolylallylsulfoxide was not studied. However, we have been successful in obtaining a very elegant method for the introduction of alkyl, aryl, alkenyl or allyl group at the 4-position of 2-azetidinone. The formation of a carbon-carbon bond at the C-4 position of a 3 -lactam might be very useful in the synthesis of carbapenem type antibiotics. 


\section{EXPERIMENTAL}

General - Flash chromatography was carried out using E. Merck silica gel 60 ( 230 - 400 mesh). Infrared spectra (IR) were recorded on a PerkinElmer 1330 spectrophotometer. Proton and carbon nuclear magnetic resonance spectra ( ${ }^{1} \mathrm{H}$ and ${ }^{13} \mathrm{C}$ NMR) were obtained on a Bruker WM-400 (400 MHz for proton and $100 \mathrm{MHz}$ for carbon). Mass spectra (MS) were recorded on a Finnlgan automated gas chromatograph EI-CI mass spectrometer.

4-Acetoxy-2-azetidinone (6) was prepared by following the reported method. 5

\section{Preparation of 4-n-butylazetidin-2-one( 8 )}

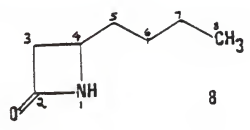

To a stirred mixture of 1.26258 ( 5 moles) of CuI.MeSMe ${ }^{17}$ in $20 \mathrm{ml}$ of ether under argon at $-20^{\circ} \mathrm{C}$ was added $6.25 \mathrm{ml}$ ( 10 mmoles) of nBuLi( $\left.1.6 \mathrm{M}\right)$. The reaction solution was stirred at $-20^{\circ} \mathrm{C}$ for 15 mins. and then $20 \mathrm{ml}$ of dimethylsulfide was added. This cuprate solution was cooled to $-50^{\circ} \mathrm{C}$ and a solution of $0.645 \mathrm{~g}$ ( $5 \mathrm{mmol}$ ) of azetidinone $\underline{6}$ in $6 \mathrm{ml}$ of ether was added. The resulting brownish red solution was stirred at $-50^{\circ} \mathrm{C}$ for $1 \mathrm{hr}$, poured into a mixture of $80 \mathrm{ml}$ of satd. $\mathrm{NH}_{4} \mathrm{Cl}$ and $20 \mathrm{ml}$ of conc. $\mathrm{NH}_{4} \mathrm{OH}$, stirred for $10 \mathrm{mins}$. and extracted three times with ether. The organic layer was washed with brine, dried $\left(\mathrm{MgSO}_{4}\right)$, concentrated and elash chromatographed on silica gel (230 - 400 mesh; $\mathrm{CH}_{2} \mathrm{Cl}_{2}$ : acetone as eluent) to give $0.571 \mathrm{~g}$ ( $94 \%$ yield) of 8 . 
Mass Spectra* $*\left(\mathrm{CI}, 70 \mathrm{eV}, 80^{\circ} \mathrm{C}\right) 128(\mathrm{M}+1,100 \%) ;\left(\mathrm{EI}, 70 \mathrm{eV}, 45^{\circ} \mathrm{C}\right)$ $128(M+1,47 \%), 117(3 \%), 110(5 \%), 84\left(M-C_{3} H_{7}, 62 \%\right), 69\left(M-C_{4} H_{10}, 49 \%\right)$, $56\left(\mathrm{M}-\mathrm{C}_{3} \mathrm{H}_{5} \mathrm{NO}, 100 \%\right)$.

IR(neat) $v_{\mathrm{cms}^{-1}}+3250$ (s, broad, $\mathrm{N}-\mathrm{H}$ stretch) 2900 (s, C-H stretch), 1725 (s,C=0 stretch), 1460 (m), 1415 (w), 1370 (m), 1180 (s), 1075 (m), 965 (s), $900(\mathrm{~m})$.

${ }^{1} \mathrm{H} \mathrm{NMR}\left(\mathrm{CDCl}_{3}\right) \delta^{*}+6.13$ (broad peak, $\left.1 \mathrm{H}, \mathrm{N}-\mathrm{H}\right), 3.58-3.63(\mathrm{~m}, 1 \mathrm{H}, \mathrm{C}-$ $4 \mathrm{H}), 3.05(d, d, d, c-3 \mathrm{H}, J=2.2,5,14.7 \mathrm{~Hz}), 2.56(d, d, d, c-3 \mathrm{H}, J=1.3$, $2.2,14.7 \mathrm{~Hz}), 1.57-1.78\left(\mathrm{~m}, 2 \mathrm{H}, \mathrm{CH}_{2}\right), 1.24-1.41\left(\mathrm{~m}, 4 \mathrm{H}, 2 \mathrm{CH}_{2}\right), 0.92(\mathrm{t}$, $3 \mathrm{H}, \mathrm{CH}_{3}, \mathrm{~J}=7 \mathrm{~Hz}$ ).

${ }^{13} \mathrm{CNMR}\left(\mathrm{CDCl}_{3}\right) \delta^{*}+168.6(s, C=0), 47.9(d, c-4), 43.1(t, c-3), 34.9$ $(t, c-5), 28.1(t, c-6), 22.2(t, c-7), 13.1(q, c-8)$.

B.P. $-100^{\circ} \mathrm{C} / 0.4 \mathrm{~mm} .\left(11 \mathrm{t} .8\right.$ bp $\left.85^{\circ} / 0.2 \mathrm{~mm}\right)$.

*Note + The 8 -lactam $\underline{8}$ shows the parent peak at $128(M+1,100 \%)$ in the EI Mass spectra which indicates that the $\beta$-lactam $\underline{8}$ has been protonated by an acid. This can possibly occur elther in the column during purification or by atmosphere. The EI Mass spectra of a mixture of acetophenone and $\beta$-lactam $\underline{8}$ was taken and $(M+1)$ peaks were observed for acetophenone $(121,50 \%)$ and 8 -lactam $\underline{8}(128,100 \%)$. When EI Mass spectra of acetophenone is run alone only $\mathrm{M}^{+}(120,50 \%)$ peak is observed. The literature ${ }^{8}$ reports several 4 -substituted azetidinones showing $(M+1)$ peak in the EI Mass spectra and no $\mathrm{M}^{+}$.

The copies of the spectra are attached in the appendix. 


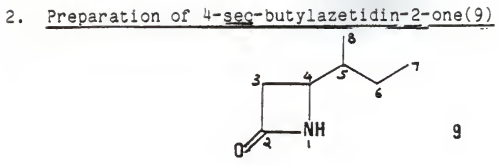

To a stirred mixture of 1.26258 ( 5 mmoles) of CuI.MeSMe ${ }^{17}$ in $20 \mathrm{ml}$ of ether under argon at $-50^{\circ} \mathrm{C}$ was added $7.5 \mathrm{ml}(10 \mathrm{mmol})$ of $\mathrm{sec}-B u 11$ ( $\left.1.35 \mathrm{M}\right)$. The $-50^{\circ} \mathrm{C}$ bath was replaced by a $-20^{\circ} \mathrm{C}$ bath and the reaction solution was stirred at $-20^{\circ} \mathrm{C}$ for $15 \mathrm{mins}$. The $-20^{\circ} \mathrm{C}$ bath was again replaced by a $-50^{\circ} \mathrm{C}$ bath and $20 \mathrm{ml}$ of dimethylsulfide was added. To this cuprate solution at $50^{\circ} \mathrm{C}$ was added a solution of 0.3238 (2.5 mmoles) of azetidinone $\underset{\sigma}{6}$ in $5 \mathrm{ml}$ of ether. The resulting brownish red solution was stirred at $-50^{\circ} \mathrm{C}$ for $1 \mathrm{hr}$, poured into a mixture of $80 \mathrm{ml}$ of satd. $\mathrm{NH}_{4} \mathrm{Cl}$ and $20 \mathrm{ml}$ of conc. $\mathrm{NH}_{4} \mathrm{OH}$, stirred for $10 \mathrm{mins}$. and extracted three times with ether. The organic layer was washed with orine, dried $\left(\mathrm{MgSO}_{4}\right)$, concentrated and flash chromatographed on silica gel (230 - 400 mesh); $\mathrm{CH}_{2} \mathrm{Cl}_{2}$ : acetone as eluent) to give 0.3058 ( $96 \%$ yield) of 2 .

Mass spectra $\div\left(\mathrm{CI}, 70 \mathrm{eV}, 45^{\circ} \mathrm{C}\right) 128(\mathrm{M}+1,100 \%) ;\left(\mathrm{EI}, 70 \mathrm{eV}, 45^{\circ} \mathrm{C}\right), 128$ $(M+1,100), 111(2 \%), 97(1.4 \%), 84\left(M-C_{3} H_{7}, 67 \%\right), 69\left(M-C_{4} H_{10}, 81 \%\right), 56$ $\left(M-C_{3} H_{5} \mathrm{NO}, 34 \%\right)$.

$\frac{\operatorname{IR}\left(\text { neat) } v_{\mathrm{cms}^{-1}}\right.}{1740(\mathrm{~s}, \mathrm{C}=0 \text { stretch })} 1460(\mathrm{~m}), 1420(\mathrm{w}), 1375(\mathrm{~m}), 1190(\mathrm{~m}), 1045(\mathrm{w}), 1025(\mathrm{w})$.

$1_{\mathrm{H} \mathrm{NMR}}\left(\mathrm{CDCl}_{3}\right) \delta+6.25$ (broad peak, $\left.1 \mathrm{H}, \mathrm{N}-\mathrm{H}\right), 3.35(\mathrm{~d}, \mathrm{~d}, \mathrm{~d}, 1 \mathrm{H}, \mathrm{C}-4 \mathrm{H}$, $\mathrm{J}=2.2,5,10 \mathrm{~Hz}), 2.97(\mathrm{~m}, 1 \mathrm{H}, \mathrm{C}-3 \mathrm{H}), 2.56-2.63(\mathrm{~m}, 1 \mathrm{H}, \mathrm{C}-3 \mathrm{H}), 1.4-1.52$ $(\mathrm{m}, 1 \mathrm{H}, \mathrm{C}-5 \mathrm{H}), 1.1-1.3\left(\mathrm{~m}, 2 \mathrm{H}, \mathrm{CH}_{2}\right), 0.8-1(\mathrm{~m}, 6 \mathrm{H}, 2 \mathrm{Me})$. 
${ }^{13}{ }_{\mathrm{C} \mathrm{NMR}}\left(\mathrm{CDCl}_{3}\right) \delta+168.6(\mathrm{~s}, \mathrm{C}=0) ; 52.0,52.4(2 \mathrm{~d}, \mathrm{C}-4) ; 40.1,40.8(2 \mathrm{t}$, $c-3) ; 38.2,38.3(2 d, c-5) ; 23.9,24.7(2 t, c-6) ; 12.4,13.2\left(2 q, \mathrm{CH}_{3}\right) ; 9.3$, $9.6\left(2 \mathrm{q}, \mathrm{CH}_{3}\right)$.

B.P.: $85^{\circ} \mathrm{C} / 0.3 \mathrm{~mm}$.

Note: Except for $\mathrm{C}=0,2$ peaks are seen for every other carbon atoms of the 2 diastereoisomers.

\section{Preparation of 4-t-butylazetidin-2-one(10)}

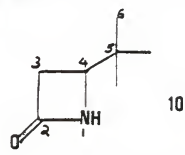

To a stirred mixture of $1.2625 \mathrm{~g}$ ( 5 mmoles) of CuI.MeSMe ${ }^{17}$ in $20 \mathrm{ml}$ of ether under argon at $-50^{\circ} \mathrm{C}$ was added $5.6 \mathrm{ml}$ (10 mmoles) of $\mathrm{t}$-BuLI (1.8 M). The $-50^{\circ} \mathrm{C}$ bath was replaced by a $-20^{\circ} \mathrm{C}$ bath and the reaction solution was stirred at $-20^{\circ} \mathrm{C}$ for 15 mins.. The $-20^{\circ} \mathrm{C}$ bath was again replaced by a $-50^{\circ} \mathrm{C}$ bath and $20 \mathrm{ml}$ of dimethylsulfide was added. To this cuprate solution at $-50^{\circ} \mathrm{C}$ was added a solution of $0.323 \mathrm{~g}$ ( 2.5 mmoles) of azetidinone 5 in $5 \mathrm{ml}$ of ether. The resulting brownish red solution was stirred at $-50^{\circ} \mathrm{C}$ for 1 $\mathrm{hr}$, poured into a mixture of $80 \mathrm{ml}$ of satd. $\mathrm{NH}_{4} \mathrm{Cl}$ and $20 \mathrm{ml}$ of conc. $\mathrm{NH}_{4} \mathrm{OH}$, stirred for $10 \mathrm{mins}$. and extracted three times with ether. The organic layer was washed with brine, dried $\left(\mathrm{MgSO}_{4}\right)$, concentrated and ilash chromatographed on silica gel (230 - 400 mesh; $\mathrm{CH}_{2} \mathrm{Cl}_{2}$ : acetone as eluent) to give 0.2858 ( $90 \%$ yield) of 10 .

Mass Spectra $+\left(\mathrm{CI}, 70 \mathrm{eV}, 30^{\circ} \mathrm{C}\right) 128(\mathrm{M}+1,100 \%),\left(\mathrm{EI}, 70 \mathrm{eV}, 25^{\circ} \mathrm{C}\right) 128$ $(M+1,19 \%), 99(7.5 \%), 84\left(M-C_{3} H_{7}, 100 \%\right), 69\left(M-C_{4} H_{10}, 85 \%\right), 57\left(M-C_{3} H_{4} N O\right.$, 83\%). 


\begin{abstract}
IR $($ Nujol $) v_{\mathrm{cms}^{-1}}+3180(\mathrm{~s}$, broad, $\mathrm{N}-\mathrm{H}), 2900$ (s, C-H stretch), 1700 (s, broad, $C=0$ stretch), 1460 (s), 1410 (w), 1350 (s), 1285 (w), 1210 (w), $1195(\mathrm{~s}), 1010(\mathrm{~s}), 980(\mathrm{~m}), 960(\mathrm{~s}), 935(\mathrm{~m})$.
\end{abstract}

$1_{\mathrm{H} \mathrm{NMR}}\left(\mathrm{CDCl}_{3}\right) \delta+6.25(\operatorname{broad}, 1 \mathrm{H}, \mathrm{N}-\mathrm{H}), 3.43(\mathrm{~d}, \mathrm{~d}, \mathrm{~d}, 1 \mathrm{H}, \mathrm{C}-4 \mathrm{H}, \mathrm{J}=1.3$, $2.6,5 \mathrm{~Hz}), 2.81-2.87(\mathrm{~m}, 1 \mathrm{H}, \mathrm{c}-3 \mathrm{H}, \mathrm{J}=\mathrm{c} . \mathrm{a} .1 .2 \mathrm{~Hz}), 2.68(\mathrm{~d}, \mathrm{~d}, \mathrm{~d}, 1 \mathrm{H}, \mathrm{c}-3 \mathrm{H}$, $\mathrm{J}=1.3,2.6,15 \mathrm{~Hz}), 0.92$ (broad $\mathrm{s}, 9 \mathrm{H}, \mathrm{CMe}_{3}$ ).

$\frac{13 \mathrm{CNMR}\left(\mathrm{CDCl}_{3}\right) \delta}{(s, c-5), 24.5(q, c-6)}+168.8(s, c=0), 56.7(d, c-4), 38.2(t, c-3), 31.7$

MP $-69^{\circ} \mathrm{C}$.

4. (a) Preparation of 1-t-butyldimethylsilyloxy-3-11thiopropane

To $2.58 \mathrm{~g}$ (10 mmoles) of 1 -t-butyldimethylsilyloxy-3-bromopropane in 10 $m 1$ of ether under argon at room temperature was added $0.35 \mathrm{~g}$ (0.05g. atoms) of finely cut lithium. After stirring at room temperature for $1 \mathrm{hr}$, the product (1-t-butyldimethylsilyloxy-3-1ithlopropane) was taken for cuprate formation as shown in part (b).

Y1eld $=70 \%$. 
(b) Preparation of 4-t-butyldimethylsilyloxypropylazetidin-2-one(11)

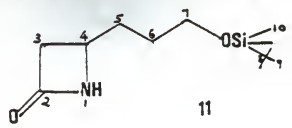

To a stirred mixture of $0.884 \mathrm{~g}$ ( 3.5 mmoles) of CuI.MeSMe ${ }^{17}$ in $10 \mathrm{ml}$ of ether under argon at $-20^{\circ} \mathrm{C}$ was added a solution of 1 -t-butyldimethylsilyloxy-3-1ithiopropane $(7.0$ mmoles) in $10 \mathrm{ml}$ of ether. The reaction solution was stirred at $-20^{\circ} \mathrm{C}$ for $15 \mathrm{mins}$ and then was added $20 \mathrm{ml}$ of dimethylsulfide. This cuprate solution was cooled to $-50^{\circ} \mathrm{C}$ and added a solution of $0.226 \mathrm{~g}$ ( $1.75 \mathrm{mmoles})$ of azetidinone 6 in $6 \mathrm{ml}$ of ether. The resulting reddish solution was stirred at $-50^{\circ} \mathrm{C}$ for $30 \mathrm{mins}$, poured into a mixture of $80 \mathrm{ml}$ of satd. $\mathrm{NH}_{4} \mathrm{Cl}$ and $20 \mathrm{ml}$ of conc. $\mathrm{NH}_{4} \mathrm{OH}$, stirred for 10 mins. and extracted three times with ether. The organic layer was washed with brine, dried $\left(\mathrm{MgSO}_{4}\right)$, concentrated and flash chromatographed on silica gel (230 - 400 mesh; $\mathrm{CH}_{2} \mathrm{Cl}_{2}$ : acetone as eluent) to give $0.420 \mathrm{~g}$ ( $98 \%$ yield) of 11 .

Mass Spectra $+\left(\mathrm{CI}, 70 \mathrm{eV}, 35^{\circ} \mathrm{C}\right) 244(\mathrm{M}+1,69 \%),\left(\mathrm{EI}, 30 \mathrm{eV}, 35^{\circ} \mathrm{C}\right), 244$ $(M+1,4 \%), 186\left(M-\mathrm{CMe}_{3}, 74 \%\right), 156(3 \%), 144(100 \%), 101(12 \%), 84(40 \%)$, $75(9 \%), 59(15 \%)$.

IR (neat) $\mathrm{C}_{\mathrm{cms}}{ }^{-1}+3300(\mathrm{~m}$, broad, $\mathrm{N}-\mathrm{H}$ stretch), 2900 (s, C-H stretch), $1730(\mathrm{~s}, C=0$ stretch) $1460(\mathrm{w}), 1250(\mathrm{~m}), 1100(\mathrm{~s}), 840(\mathrm{~s}), 730(\mathrm{~m})$. 
$1_{\mathrm{HNMR}}\left(\mathrm{CDCl}_{3}\right) \delta+6.04$ (broad s, $\left.1 \mathrm{H}, \mathrm{N}-\mathrm{H}\right), 3.64\left(\mathrm{~m}, 3 \mathrm{H}, \mathrm{CH}_{2} \mathrm{O}\right.$ and $\mathrm{CHN}), 3.05(d, d, d, 1 \mathrm{H}, \mathrm{C}-3 \mathrm{H}, J=2.2,5.0,14.7 \mathrm{~Hz}), 2.56(d, d, d, 1 \mathrm{H}, \mathrm{C}-3 \mathrm{H}$, $J=1.3,2.2,14.7 \mathrm{~Hz}), 1.7\left(\mathrm{~m}, 2 \mathrm{H}, \mathrm{CH}_{2}\right), 1.53\left(\mathrm{~m}, 2 \mathrm{H}, \mathrm{CH}_{2}\right), 0.9(\mathrm{~s}, 9 \mathrm{H}$, $\left.\mathrm{CMe}_{3}\right), 0.04\left(\mathrm{~s}, 6 \mathrm{H}, \mathrm{SiMe}_{2}\right)$.

${ }^{13} \mathrm{C} \mathrm{NMR}_{\left(\mathrm{CDCl}_{3}\right) \delta}+168.3(\mathrm{~s}, \mathrm{C}=0), 62.4(t, C-7), 47.8(\mathrm{~d}, \mathrm{C}-4), 43.3$ $(t, \overline{c-3}), 32.1(t, c-5), 29.3(t, c-6), 25.8(q, c-9), 18.1(s, c-8),-5.5$ $(q, c-10)$.

BP $-130^{\circ} \mathrm{C} / 0.3 \mathrm{~mm}$.

5. (a) Preparation of 2-(2-bromothy1)-1,3-dioxolane(19) 16

To a stirred solution of $4 \mathrm{~g}$ (0.05 moles) of $\mathrm{HBr}$ in $6.7 \mathrm{~g}$ ( 0.108 moles) of ethylene glycol was added, at $5-10^{\circ} \mathrm{C}, 1.87 \mathrm{~g}(0.033$ moles $)$ of acrolein. After stirring for $1 \mathrm{hr}$. at room temperature the mixture was extracted three times with hexane. The organic layer was washed with $5 \% \mathrm{NaHCO}_{3}$, dried $\left(\mathrm{Na}_{2} \mathrm{SO}_{4}\right)$ and concentrated. Distillation of the residue afforded $3.6 \mathrm{~g}(61 \%$ yield) of bromide 12 .

B.P. $-65^{\circ} \mathrm{C} / 5 \mathrm{~mm}$.

${ }_{\mathrm{HNMR}\left(\mathrm{CDCl}_{3}\right) \delta} \div 5.0\left(t, 1 \mathrm{H}, \mathrm{CHO}_{2}, J=3.8 \mathrm{~Hz}\right), 3.9(\mathrm{~m}, 4 \mathrm{H}$,
$\left.-0-\mathrm{CH}_{2}-\mathrm{CH}_{2}-\mathrm{O}-\right), 3.46\left(t, 2 \mathrm{H}, \mathrm{CH}_{2} \mathrm{Br}, J=6.4 \mathrm{~Hz}\right), 2.2\left(\mathrm{~m}, 2 \mathrm{H}, \mathrm{CH}_{2}\right)$.

(b) Preparation of 3,3-ethylenedioxyoropylmagnesium bromide

The Grignard reagent was prepared by addition of $2.8 \mathrm{~g}$ ( 15.5 mmoles) of bromide 19 in $10 \mathrm{ml}$ of dry tetrahydrofuran (THF) under argon to $0.45 \mathrm{~g}$ $\left(0.0186 \mathrm{~g}\right.$ atom) of magnesium over a period of $45 \mathrm{mins}$. at $30-35^{\circ} \mathrm{C}$. Stirring was continued for $1 \mathrm{hr}$. at $30^{\circ} \mathrm{C}$ and the reagent was used up immediately for cuprate formation (Part c). 
Yield $=70 \%$.

(c) Preparation of 4-(3,3-ethylenedioxypropy 1)-2-azetidinone(12)

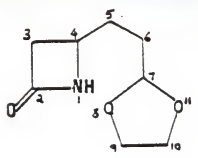

12

To a stirred mixture of $1.369 \mathrm{~g}$ ( $5.42 \mathrm{mmoles}$ ) of CuI.MeSMe ${ }^{17}$ in $10 \mathrm{ml}$ of ether under argon at $-20^{\circ} \mathrm{C}$ was added the Grignard reagent (prepared in part b) (10.85 mmoles) in $10 \mathrm{ml}$ of THF. The reaction solution was stirred at $20^{\circ} \mathrm{C}$ for $15 \mathrm{mins}$. and then was added $20 \mathrm{ml}$ of dimethylsulfide. This cuprate solution was cooled to $-50^{\circ} \mathrm{C}$ and added a solution of $0.35 \mathrm{~g}$ (2.71 mmoles) of azetidinone 6 in $5 \mathrm{ml}$ of ether. The reaction solution was stirred at $-50^{\circ} \mathrm{C}$ for 15 mins. and then warmed to $0^{\circ} \mathrm{C}$ over a period of $45 \mathrm{mins}$. The resulting dark blue colored solution was poured into a mixture of $80 \mathrm{ml}$ of satd. $\mathrm{NH}_{4} \mathrm{Cl}$ and $20 \mathrm{ml}$ of conc. $\mathrm{NH}_{4} \mathrm{OH}$, stirred for $10 \mathrm{mins}$. and extracted once with ether, followed by $\mathrm{six}$ extractions with $\mathrm{CH}_{2} \mathrm{Cl}_{2}$. The organic layer was washed with brine, dried $\left(\mathrm{MgSO}_{4}\right)$ concentrated and flash chromatographed on silica gel (230 - 400 mesh; $\mathrm{CH}_{2} \mathrm{Cl}_{2}$ : acetone as eluent) to give $0.426 \mathrm{~g}$ (92\% yield) of 12 .

Mass Spectra $+\left(\right.$ CI, $\left.70 \mathrm{eV}, 110^{\circ} \mathrm{C}\right) 171(\mathrm{M}+1,70 \%),\left(\mathrm{EI}, 70 \mathrm{eV}, 120^{\circ} \mathrm{C}\right)$, $170\left(M^{+}, 8 \%\right), 141\left(M-C_{2} H_{5}, 3 \%\right), 125(10 \%), 98(5 \%), 86(5 \%), 72(100 \%)$.

IR (neat) $v_{\mathrm{cms}^{-1}}+-3300$ (s, broad, $\left.\mathrm{N}-\mathrm{H}\right), 2900$ (s, C-H stretch), 1725 $(\mathrm{s}, \mathrm{C}=0$ stretch), 1375 (s), 1275 (w), 1180 (w), 1125 (m), 1025 (m), 950 (m), $875(\mathrm{~m})$. 
${ }_{\mathrm{HNMR}}\left(\mathrm{CDCl}_{3}\right) \mathrm{s} \div 6.5$ (broad $\left.\mathrm{s}, 1 \mathrm{H}, \mathrm{N}-\mathrm{H}\right), 4.88\left(\mathrm{t}, 1 \mathrm{H}, \mathrm{CHO}_{2}, \mathrm{~J}=\right.$ $3.8 \mathrm{~Hz}), 3.9\left(\mathrm{~m}, 4 \mathrm{H}, \mathrm{CH}_{2} \mathrm{O}\right), 3.66(\mathrm{~m}, 1 \mathrm{H}, \mathrm{C}-4 \mathrm{H}), 3.03-3.09(\mathrm{~d}, \mathrm{~d}, \mathrm{~d}, 1 \mathrm{H}, \mathrm{c}-3 \mathrm{H}$, $J=1,2.2,14.8 \mathrm{~Hz}), 2.57(d, d, d, 1 \mathrm{H}, C-3 \mathrm{H}, J=1.2,2.2,14.8 \mathrm{~Hz}), 1.7-1.8$ $\left(\mathrm{m}, 4 \mathrm{H}, \mathrm{CH}_{2}\right.$ at $\mathrm{C}_{5}$ and $\left.\mathrm{C}_{6}\right)$

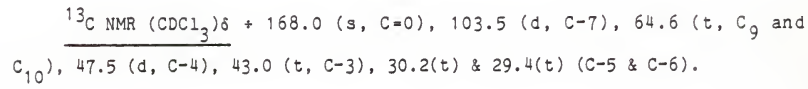

6. (a) Preparation of vinylitithium

To a stirred solution of 28 ( 0.0187 moles) of vinylbromide in $20 \mathrm{ml}$ of ether at $-100^{\circ} \mathrm{C}$ (11quid nitrogen-pentane bath), is added $11.5 \mathrm{ml}(0.0206$ moles) of t-But $1(1.8 \mathrm{M})$. After stirring at $-100^{\circ} \mathrm{C}$ for $15 \mathrm{mins}$, the 11 quid nitrogen-pentane bath is replaced by a dry ice-acetone bath and the reaction contents are stirred at $-78^{\circ} \mathrm{C}$ for $1 \mathrm{hr}$. The dry 1 ce-acetone bath is next replaced by an ordinary ice bath and the reaction contents were stirred at $0^{\circ} \mathrm{C}$ for $1 \mathrm{hr}$.. After $1 \mathrm{hr}$. the reaction contents were warmed to room temperature. Vinylilthium was next standardized as shown in part (b).

\section{(b) Standardization of vinyli ithium}

To $26 \mathrm{mg}(0.122$ moles) of diphenylacetic acid dissolved in $0.5 \mathrm{ml}$ of ThF at $0^{\circ} \mathrm{C}$ is added dropwise vinylithlum prepared as shown in part (a). End point of the titration is indicated by the solution turning yellow.

The prepared vinyllithium standardized in this manner was found to be $0.20 \mathrm{M}$. 
(c) Preparation of 4-vinylazetidin-2-one(13)

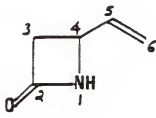

13

To a stirred mixture of 0.5258 (2.08 mmoles) of CuI *MeSMe ${ }^{17}$ in $5 \mathrm{ml}$ of ether under argon at $-30^{\circ} \mathrm{C}$ was added $25 \mathrm{ml}$ of vinyllithium $(0.20 \mathrm{M})$. The reaction solution was stirred at $-20^{\circ} \mathrm{C}$ for $15 \mathrm{mins}$, and then was added $30 \mathrm{ml}$ of dimethylsulfide. This cuprate solution was cooled to $-50^{\circ} \mathrm{C}$ and a solution of $0.1078(0.832 \mathrm{mmoles})$ of azetidinone $\underline{6}$ in $2 \mathrm{ml}$ of ether $1 \mathrm{~s}$ added. The resulting black solution was stirred at $-50^{\circ} \mathrm{C}$ for $30 \mathrm{mins}$, poured into a mixture of $80 \mathrm{ml}$ of satd. $\mathrm{NH}_{4} \mathrm{Cl}$ and $20 \mathrm{ml}$ of conc. $\mathrm{NH}_{4} \mathrm{OH}$, stirred for $10 \mathrm{mins}$. and extracted three times with ether. The organic layer was washed with brine, dried $\left(\mathrm{MgSO}_{4}\right)$, concentrated and Plash chromatographed on silica gel (230 - 400 mesh; ethylacetate: Hexane as eluent) to give $60 \mathrm{mg}(75 \% \mathrm{yield})$ of 13 .

Mass Spectra $*\left(\mathrm{CI}, 70 \mathrm{eV}, 30^{\circ} \mathrm{C}\right), 97\left(\mathrm{M}^{+}, 44 \%\right),\left(\mathrm{EI}, 70 \mathrm{eV}, 30^{\circ} \mathrm{C}\right) 97 \mathrm{M}^{+}$, $44 \%), 80(2 \%), 67(13 \%), 53(100 \%)$.

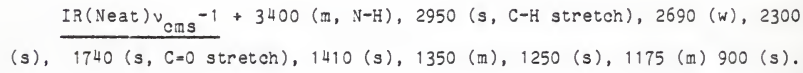




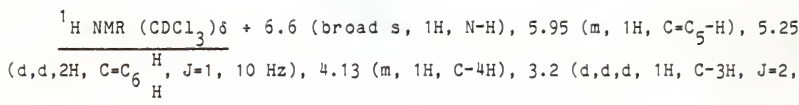
$5.2,14.8 \mathrm{~Hz}), 2.7(d, d, d, 1 \mathrm{H}, c-3 \mathrm{H}, J=1.3,2.4,14.8 \mathrm{~Hz})$,

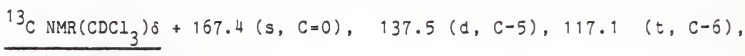
$49.5(d, c-4), 45.2(t, c-3)$.

\section{7. (a) Preparation of 1-1ithiocyclohexene}

To $0.805 \mathrm{~g}$ ( 5 mmoles) of 1-bromocyclohexene in $5 \mathrm{ml}$ of ether under argon at room temperature was added $0.175 \mathrm{~g}$ ( $0.025 \mathrm{~g}$-atoms) of finely cut lithium. After stirring at room temperature for $1 \mathrm{hr}$., the product (1-lithiocyclohexene) was taken for cuprate formation as shown in part (b). Yield $=70 \%$.

(b) Preparation of 4-(1-cyclohexeny1)-azetidin-2-one(14)

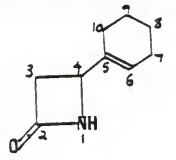

14

To a stirred mixture of $0.422 \mathrm{~g}$ ( 1.75 mmoles) of CuI.MeSMe ${ }^{17}$ in $5 \mathrm{ml}$ of ether under argon at $-20^{\circ} \mathrm{C}$ was added a solution of $1-1$ ithiocyclohexene $(3.5$ mmoles) in $5 \mathrm{ml}$ of ether. The reaction solution was stirred at $-20^{\circ} \mathrm{C}$ for 15 mins. and then was added $10 \mathrm{ml}$ of dimethylsulfide. This cuprate solution was cooled to $-50^{\circ} \mathrm{C}$ and added a solution of 0.1138 ( 0.875 mmoles) of azetidinone 6 in $3 \mathrm{ml}$ of ether. The resulting dark green solution was stirred at $-50^{\circ} \mathrm{C}$ for 30 mins., poured into a mixture of $80 \mathrm{ml}$ of satd. $\mathrm{NH}_{4} \mathrm{Cl}$ and $20 \mathrm{ml}$ of conc. $\mathrm{NH}_{4} \mathrm{OH}$, stirred for $10 \mathrm{mins}$. and extracted three times 
with ether. The organic layer was washed with brine, dried $\left(\mathrm{MgSO}_{4}\right)$, concentrated and flash chromatographed on silica gel (230-400 mesh), $\mathrm{CH}_{2} \mathrm{Cl}_{2}$; acetone as eluent) to give $0.125 \mathrm{~g}$ ( $95 \%$ yield) of 14 .

Mass Spectra $*\left(\mathrm{CI}, 70 \mathrm{eV}, 60^{\circ} \mathrm{C}\right) 152(\mathrm{M}+1,100 \%)$; (EI, $\left.70 \mathrm{eV}, 50^{\circ} \mathrm{C}\right)$, $151\left(\mathrm{M}^{+}, 70 \%\right), 122\left(\mathrm{M}-\mathrm{C}_{2} \mathrm{H}_{5}, 21 \%\right), 108\left(\mathrm{M}-\mathrm{C}_{3} \mathrm{H}_{7}, 100 \%\right), 93\left(\mathrm{M}-\mathrm{C}_{4} \mathrm{H}_{10}, 76 \%\right), 79$ $(61 \%), 67(48 \%), 53(27 \%)$.

IR (Nujol) $v_{\mathrm{cms}^{-1}}+3175(\mathrm{~m}, \mathrm{~N}-\mathrm{H}$ stretch), 2880 (s, C-H stretch), 1700 (s, C=0 stretch), 1450 (s), 1365 (s), 1260 (m), 1175 (m), 910 (w).

$1_{\mathrm{H} \mathrm{NMR}}\left(\mathrm{CDCl}_{3}\right) \delta+5.8(\operatorname{broad} \mathrm{s}, 1 \mathrm{H}, \mathrm{N}-\mathrm{H}), 5.64(\operatorname{broad} \mathrm{s}, \mathrm{C}=\mathrm{C}-\mathrm{H}), 3.95$ $(\mathrm{m}, 1 \mathrm{H}, \mathrm{C}-4 \mathrm{H}), 2.97-3.04(\mathrm{~d}, \mathrm{~d}, \mathrm{~d}, 1 \mathrm{H}, \mathrm{C}-3 \mathrm{H}, \mathrm{J}=1.75,3.4,15.1 \mathrm{~Hz}), 2.62$ $(d, d, d, 1 \mathrm{H}, c-3 \mathrm{H}, \mathrm{J}=1.3,1.3,14 \mathrm{~Hz}), 1.82-1.96\left(\mathrm{~m}, 4 \mathrm{H}, \mathrm{CH}_{2}\right.$ at $\mathrm{C}_{7}$ and $\left.\mathrm{C}_{10}\right)$, $1.44-1.65\left(\mathrm{~m}, 4 \mathrm{H}, \mathrm{CH}_{2}\right.$ at $\mathrm{C}_{8}$ and $\left.\mathrm{c}_{9}\right)$.

\footnotetext{
${ }^{13} \mathrm{CNMR}\left(\mathrm{CDCl}_{3}\right) \delta+168.4(s, C=0), 135.8(s, c-5), 123.2(d, c-6), 51.8$ $(d, c-4), 43.2(t, c-3), 24.7(t), 23.3(t)(c-7 \& c-10), 22.2\left(t, 2 c, c_{8}\right.$ and $c_{9}$ ).

M.P. $-60^{\circ} \mathrm{C}$.
} 
8. Preparation of 4-phenylazetidin-2-one(15)

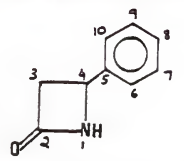

To a stirred mixture of $1.2625 \mathrm{~g}$ ( 5 mmoles) of CuI $\cdot M e S M e^{17}$ in $20 \mathrm{ml}$ of ether under argon at $-20^{\circ} \mathrm{C}$ was added $5 \mathrm{ml}$ ( 10 mmoles) of PhL1 (2M). The reaction solution was stirred at $-20^{\circ} \mathrm{C}$ for $15 \mathrm{mins}$. and then was added $20 \mathrm{ml}$ of dimethylsulfide. To this cuprate solution was added a solution of $0.32 \mathrm{~g}$ ( 2.5 mmol) of azetidinone 6 in $10 \mathrm{ml}$ of ether. The resulting greenish solution was stirred at $-20^{\circ} \mathrm{C}$ for $1 \mathrm{hr}$., poured into a mixture of $80 \mathrm{ml}$ of satd. $\mathrm{NH}_{4} \mathrm{Cl}$ and $20 \mathrm{ml}$ of conc. $\mathrm{NH}_{4} \mathrm{OH}$, stirred for $10 \mathrm{mins}$. and extracted three times with ether. The organic layer was washed with brine, dried $\left(\mathrm{MgSO}_{4}\right)$, concentrated and flash chromatographed on silica gel (230 - 400 mesh; $\mathrm{CH}_{2} \mathrm{Cl}_{2}$ : acetone as eluent) to give $0.3 \mathrm{~g}$ ( $82 \%$ yield) of 15 .

Mass Spectra $+\left(C I, 70 \mathrm{eV}, 150^{\circ} \mathrm{C}\right), 148(\mathrm{M}+1,100 \%) ;(E I, 70 \mathrm{eV}$, $\left.130^{\circ} \mathrm{C}\right), 147\left(\mathrm{M}^{+}, 15 \%\right), 118$ (M-CHO, 12\%), $104(\mathrm{M}-\mathrm{C}-\mathrm{NH}, 100 \%), 91(3 \%), 77$ $(14 \%), 63(3 \%)$.

IR (Nujol) $\mathrm{cms}^{-1}+3150$ ( $\mathrm{m}$, broad, $\mathrm{N}-H$ stretch), 2900 (s, C-H stretch), 1675 (s, C=0 stretch), 1450 (m), 1360 (m), 1175 (m), 1000 (w), 975 (w), 960 (w). 
$1_{\mathrm{H} \mathrm{NMR}}\left(\mathrm{CDCl}_{3}\right) \mathrm{S}+7.3(\mathrm{~m}, 5 \mathrm{H}$, Arom. $\mathrm{H}), 6.3$ (broad $\left.\mathrm{s}, 1 \mathrm{H}, \mathrm{N}-\mathrm{H}\right), 4.73$ $(d, d, 1 \mathrm{H}, c-4 \mathrm{H}, J=2.52,5.3 \mathrm{~Hz}), 3.44(d, d, d, 1 \mathrm{H}, c-3 \mathrm{H}, J=2.5,5.314 .9$ Hz).

${ }^{13} \mathrm{CNMR}\left(\mathrm{CDCl}_{3}\right) \delta+168.4(\mathrm{~s}, \mathrm{C}=0), 140.2(\mathrm{~s}, \mathrm{c}-5), 128.7\left(\mathrm{~d}, 2 \mathrm{C}, \mathrm{c}_{6}\right.$ and $\left.c_{10}\right), 128(d, c-8), 125.5\left(d, 2 c, c_{7}\right.$ and $\left.c_{9}\right), 50.2(d, c-4), 47.7(t, c-3)$. M.P. $-106^{\circ} \mathrm{C}$.

\section{9. (a) Preparation of 1-lithionaphthalene}

To $3.44 \mathrm{~g}$ ( $16.7 \mathrm{mmoles})$ of 1-bromonaphthalene in $10 \mathrm{ml}$ of ether under argon at room temperature was added $0.588 \mathrm{~g}(0.084 \mathrm{gm}$ atoms) of finely cut lithium. After stirring at room temperature for $1 \mathrm{hr}$, , the product (1. Ithionaphthalene) was taken for cuprate formation as shown in part (b). Yield $=60 \%$.

(b) Preparation of 4-[1-naphthyl]azetidin-2-one(16)

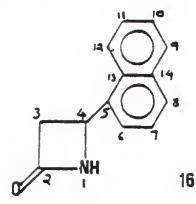


To a stirred mixture of 1.26258 ( 5 mmoles) of CuI $\cdot M_{e S M e}{ }^{17}$ in $20 \mathrm{ml}$ of ether under argon at $-20^{\circ} \mathrm{C}$ was added a solution of 1-1ithionaphthalene (10 mmoles) in $10 \mathrm{ml}$ of ether. The reaction solution was stirred at $-20^{\circ} \mathrm{C}$ for 15 mins., cooled to $-50^{\circ} \mathrm{C}$ and $20 \mathrm{ml}$ of MeSMe was added. To this cuprate solution at $-50^{\circ} \mathrm{C}$, was added a solution of $0.32 \mathrm{~g}$ (2.5 mmoles) of azetidinone $\underline{6}$ in $5 \mathrm{ml}$ of ether. The resulting dark green colored solution was stirred at $-50^{\circ} \mathrm{C}$ for $1 \mathrm{hr}$. , poured into a mixture of $80 \mathrm{ml}$ of satd. $\mathrm{NH}_{4} \mathrm{Cl}$ and $20 \mathrm{ml}$ of conc $\mathrm{NH}_{4} \mathrm{OH}$, stirred for $10 \mathrm{mins}$. and extracted three times with ether. The organic layer was washed with brine, dried $\left(\mathrm{MgSO}_{4}\right)$, concentrated and flash chromatographed on silica gel (230 - 400 mesh; $\mathrm{CH}_{2} \mathrm{Cl}_{2}$ : acetone as eluent) to give $0.39 \mathrm{~g}$ ( $80 \%$ yield) of 16 .

Mass Spectra $+\left(\mathrm{CI}, 70 \mathrm{eV}, 30^{\circ} \mathrm{C}\right) 197\left(\mathrm{M}+1,23^{\circ}\right) ;\left(\mathrm{EI}, 20 \mathrm{eV}, 35^{\circ} \mathrm{C}\right), 196$ $\left(M^{+}, 8 \%\right), 178(40 \%), 169(23 \%), 155(36 \%), 149(30 \%), 140(28 \%), 127(36 \%)$, $117(53 \%), 111(47 \%), 100(6 \%), 83(100 \%), 76(13 \%), 69(97 \%), 56(46 \%)$.

IR (Nujol) $\mathrm{Cms}_{\mathrm{cms}}{ }^{-1}+3200(\mathrm{w}, \mathrm{N}-\mathrm{H}$ stretch), 2850 (s, C-H stretch), 1725 (s, C=0 stretch), 1450 (s), 1360 (m), 1320 (w), 775 (s).

$1_{\mathrm{H} \mathrm{NMR}}\left(\mathrm{CDCl}_{3}\right) \delta+7.81-7.93(\mathrm{~m}, 3 \mathrm{H}$, Arom. H), $7.47-7.59(\mathrm{~m}, 4 \mathrm{H}$, Arom. H), 6.4 (broad $s, 1 \mathrm{H}, \mathrm{N}-\mathrm{H}), 5.42(\mathrm{~d}, \mathrm{~d}, \mathrm{H}, \mathrm{C}-4 \mathrm{H}, \mathrm{J}=2.7,5.3 \mathrm{~Hz}$ ). 3.7 $(d, d, d, 1 H, C-3 H, J=2.7,5.4,14.6 \mathrm{~Hz}), 2.9$ (d, $d, 1 \mathrm{H}, \mathrm{C}-3 \mathrm{H}, J=2.7,14.7$ $\mathrm{Hz}$ ).

${ }^{13} \mathrm{CNMR}\left(\mathrm{CDCl}_{3}\right) \delta \div 169(\mathrm{~s}, \mathrm{C}=0), 131,135,137\left(\mathrm{~s}, \mathrm{C}_{5}, \mathrm{C}_{13}, \mathrm{C}_{14}\right), 121-$ $130\left(d, 7 c, c_{6}-c_{12}\right), 49(d, c-4), 47(t, c-3)$. 
10. Preparation of 4-allylazetidin-2-one(17)

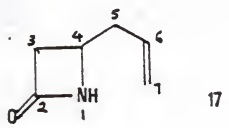

To a stirred mixture of $0.422 \mathrm{~g}$ ( 1.75 mmoles) of CuI.MeSMe ${ }^{17}$ in $5 \mathrm{ml}$ of ether under argon at $-30^{\circ} \mathrm{C}$ was added $9.2 \mathrm{ml}(3.5$ mmoles $)$ of allyllithium $(0.38 \mathrm{M})$. After stirring at $-30^{\circ} \mathrm{C}$ for $10 \mathrm{mins}$, the $-30^{\circ} \mathrm{C}$ bath was replaced. by a $-50^{\circ} \mathrm{C}$ bath and $10 \mathrm{ml}$ of dimethylsulfide was added. To this cuprate solution was added 0.1138 (0.87 mmoles) of azetidinone 6 in $5 \mathrm{ml}$ of ether. The resulting dark brown solution was warmed to $-30^{\circ} \mathrm{C}$ over a period of 1 hr., poured into a mixture of $80 \mathrm{ml}$ of satd. $\mathrm{NH}_{4} \mathrm{Cl}$ and $20 \mathrm{ml}$ of cone. $\mathrm{NH}_{4} \mathrm{OH}$, stirred for $10 \mathrm{mins}$, and extracted three times with ether. The organic layer was washed with brine, dried $\left(\mathrm{MgSO}_{4}\right)$, concentrated and flash chromatographed on silica gel (230 - 400 mesh; ethylacetate: Hexane as eluent) to give $69 \mathrm{mg}(71 \% \mathrm{yield})$ of 17 .

Mass Spectra $+\left(\mathrm{CI}, 70 \mathrm{eV}, 30^{\circ} \mathrm{C}\right) 111\left(\mathrm{M}^{+}, 100 \%\right)$ ( EI, $\left.70 \mathrm{eV}, 30^{\circ} \mathrm{C}\right), 111$ $\left(M^{+}, 67 \%\right), 103(14 \%), 95(12 \%), 82\left(M-C_{2} H_{5}, 11 \%\right), 77(1.5 \%), 69(100 \%), 66$ $(57 \%), 52(36 \%)$. 
I. (Neat) $\nu_{\mathrm{cms}}{ }^{-1}+3250$ (s, N-H stretch), 2900 (m, C-H stretch), 1725 (s, C=0 stretch), 1350 (m), $1180(\mathrm{~m}), 1060$ (m), 910 (s).

${ }^{1} \mathrm{H} \mathrm{NMR}\left(\mathrm{CDCl}_{3}\right) \delta+5.7$ (broad $\left.\mathrm{s}, 1 \mathrm{H}, \mathrm{N}-\mathrm{H}\right), 5.8$ (t), $\left.\mathrm{H}, \mathrm{C}=\mathrm{C}_{6}-\mathrm{H}\right), 5.12$ $\left(\mathrm{m}, 2 \mathrm{H}, \mathrm{C}_{6}=\mathrm{C}_{7-\mathrm{H}}^{\mathrm{H}}\right), 3.68(\mathrm{~m}, 1 \mathrm{H}, \mathrm{C}-4 \mathrm{H}), 3.03(\mathrm{~d}, \mathrm{~d}, \mathrm{~d}, 1 \mathrm{H}, \mathrm{c}-3 \mathrm{H}, \mathrm{J}=1.9,4.9$, $14.3 \mathrm{~Hz}), 2.6(d, d, d, 1 \mathrm{H}, C-3 \mathrm{H}, J=1.35,2.2,14.8 \mathrm{~Hz}), 2.48\left(\mathrm{~m}, 2 \mathrm{H}, \mathrm{CH}_{2}\right.$ at $(-5)$.

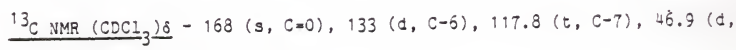
$c-4), 42.7(t, c-3), 39.3(t, c-5)$.

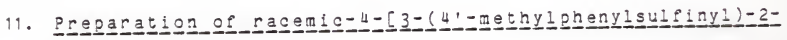
propenyl]azetidin-2-one (7)

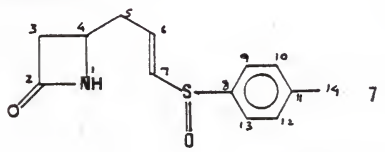

To 0.4958 ( 0.00275 moles) of racemic allylsulfoxide in $7 \mathrm{ml}$ of $\mathrm{HF}$ under argon at $-78^{\circ} \mathrm{C}$ was added 0.00275 moles of lithium di isopropylamide (LDA) [0.00275 moles of dissopropylamine, 0.00275 moles of nBuL1 (1.6 M) in $7 \mathrm{ml}$ of THF] at $-78^{\circ} \mathrm{C}$. After stirring at $-73^{\circ} \mathrm{C}$ for 1 hr., $0.16 \mathrm{~g}(0.00138$ goles) of azetidinone 6 in $5 \mathrm{ml}$ of THF was added. The resulting solution was stirred at $-78^{\circ} \mathrm{C}$ for $1 \mathrm{hr}$, diluted with satd. $\mathrm{NH}_{4} \mathrm{Cl}$, extracted inr : 20 with gethylene ohlorlde, dried $\left(\mathrm{MgSO}_{4}\right)$, concentrated and :lash chromatographed on silica gel (230 - 400 mesh; $\mathrm{CH}_{2} \mathrm{Cl}_{2}$ : acetone as eluent) to give $42 \mathrm{mg}$ ( $14 \% \mathrm{jield}$ ) of I. 
Mass Spectra $\div\left(\mathrm{CI}, 70 \mathrm{eV}, 170^{\circ} \mathrm{C}\right), 250(\mathrm{M}+1,100 \%) ;\left(\mathrm{EI}, 70 \mathrm{eV}, 160^{\circ} \mathrm{C}\right)$ $249\left(\mathrm{M}^{+}, 2 \%\right), 246(10 \%), 201(15 \%), 158\left(\mathrm{M}-\mathrm{C}_{6} \mathrm{H}_{4} \mathrm{CH}_{3}, 39 \%\right), 139(37 \%), 130$ $(20 \%), 123(100 \%), 110(11 \%), 91(89 \%), 76(37 \%), 65(79 \%)$.

${ }_{1} \mathrm{H} \mathrm{NMR}_{\left(\mathrm{CDCl}_{3}\right) \delta}+7.5(\mathrm{~m}, 2 \mathrm{H}$, Arom. H) $7.35(\mathrm{~m}, 2 \mathrm{H}$, Arom. H) 6.6 (broad s, $1 \mathrm{H}, \mathrm{N}-\mathrm{H}), 6.5\left(\mathrm{~m}, 1 \mathrm{H}, \mathrm{C}=\mathrm{C}_{6}-\mathrm{H}\right), 6.3\left(\mathrm{~d}, 1 \mathrm{H}, \mathrm{C}=\mathrm{C}_{7}-\mathrm{H}\right), 3.7(\mathrm{~m}, 1 \mathrm{H}, \mathrm{C}-$ $4 \mathrm{H}), 3.06(\mathrm{~m}, 1 \mathrm{H}, \mathrm{C}-3 \mathrm{H}), 2.63(\mathrm{~m}, 1 \mathrm{H}, \mathrm{C}-3 \mathrm{H}), 2.4\left(\operatorname{broad} \mathrm{s}, 3 \mathrm{H}, \mathrm{p}-\mathrm{CH}_{3}\right), 2.1-$ $2.7\left(\mathrm{~m}, 2 \mathrm{H}, \mathrm{CH}_{2}\right.$ at $\left.\mathrm{C}-5\right)$.

${ }^{13} \mathrm{CNMR}\left(\mathrm{CDCl}_{3}\right) \delta+167.1(s, C=0), 141.8(s, C-8), 140.3(s, c-11)$, $138.1(d, c-7), 133.3(d, c-6), 130.1(d, 2 c, c-9 \& c-13), 124.6(d, 2 C, c-$ $10 \& c-12), 46.3(d, c-4), 43.2(t, c-3), 37.6(t, c-5) 21.3(q, c-14)$. 


\section{REFERENCES}

1. Schonberg, G. A.; Arison, B. H.; Hensens, O. D.; Hirshfield, J.; Hoogsteen, K.; Kaczka, E. A.; Rhodes, R. E.; Kahan, J. S.; Kahan, F. M.; Ratcliffe, R. W.; Walton, E.; Ruswinkle, L. J.; Morin, R. B.; Christensen, B. G.; J. Am. Chem. Soc. 1978, 100, 6491.

2. McGregor, D. N. in "Comprehensive Heterocyclic Chemistry", 1st ed., Lwowski, W., Ed., Pergamom Press., New York, N. Y., 1984, Vol. 7, page 300 .

3. Johnston, D. B. R.; Schmitt, S. M.; Bouffard, F. A.; Christensen, B. G.; J. Am. Chem. Soc. 1978, 100, 313.

4. Dunn, G. L. In "Comprehensive Heterocyclic Chemistry", 1st ed., Lwowski, W. Ed., Pergamom Press., New York, N. Y., 1984, Vol. 7, page 352.

5. Clauss, K.; Grim, D.; Prossel, G.; Liebigs Ann. Chem. 1974, 539.

6. Michael, I. P.; Accts. of Chem. Research 1984, 17, 144.

7. Kobayashi, T.; Ishida, N.; Hiraoka, T.; J. Chem. Soc. Chem. Comm. 1980, 736 .

8. Kametani, T.; Honda, T.; Sasaki, J.; Terasawa, H; Fukumoto, K.; J. Chem. Soc. Perkin-I. 1981, 1884.

9. Greengrass, C.W.; Hoople, D. W. T.; Iet_-_Lett. 1981, 1161 and references therein.

10. Kraus, G. A.; Neuenschwanter, K.; J. Chem. Soc. Chem. Ccmm. 1982, 134 .

11. Shibasaki, M.; Nishida, A.; Ikegami, S.; J. Chem. Soc., Chem. Commun. 1982, 22. 1324 .

12. Filipo, J. S.; Inorg. Chem. 1978, 17, 275. . 
13. Pearson, R. G. and Gregory, C. D.; J.Am. Chem. Soc., 1976, 98, 4098.

14. Dietmar, S.; Michael, A. W.; J. Am. Chem. Soc. 1961, 83, 3583.

15. Robert, W.; Will1am, H. G.; J. Org. Chem. 1961, 26, 2096.

16. Büchi, G.; Wuest, H.; J. Org. Chem. 1969, 34, 1122.

17. House, H. O.; Chu, C. Y.; Wilkins, J. M.; Umen, M. J.; J. Org. Chem. $1975,40,1460$. 
APPENDIX 


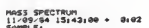

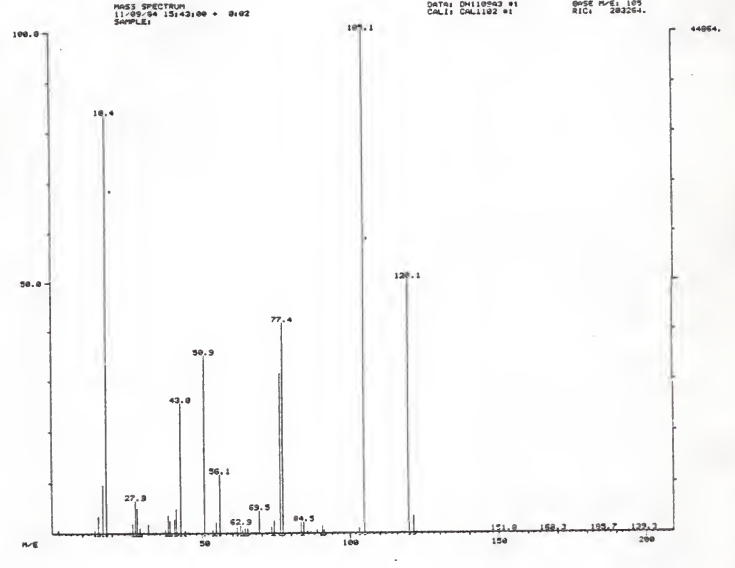


Mass SPECTRUN

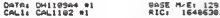

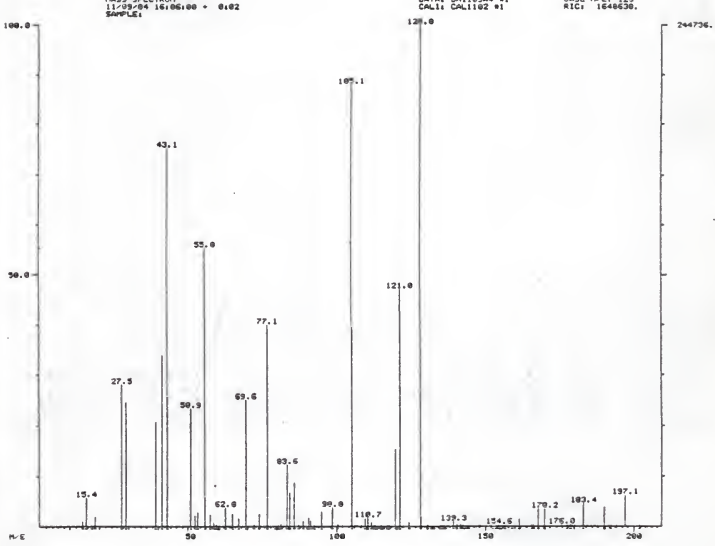


AGV-II-004

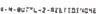
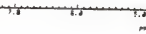
1.e.t?

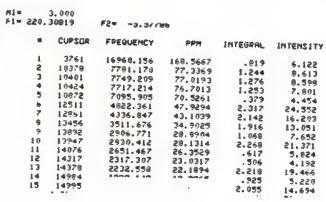

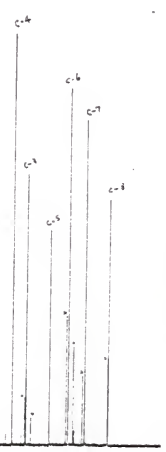

कृ

7)

औ. 3

就

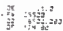

告

i...

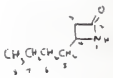

$\mathrm{CH}_{3} \mathrm{CH}_{6} \mathrm{CH}_{3}$

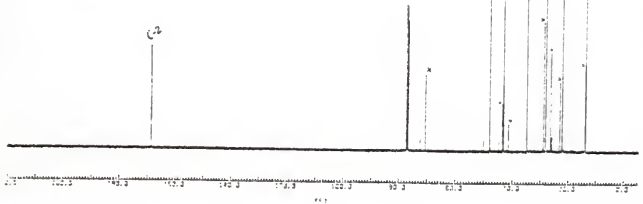




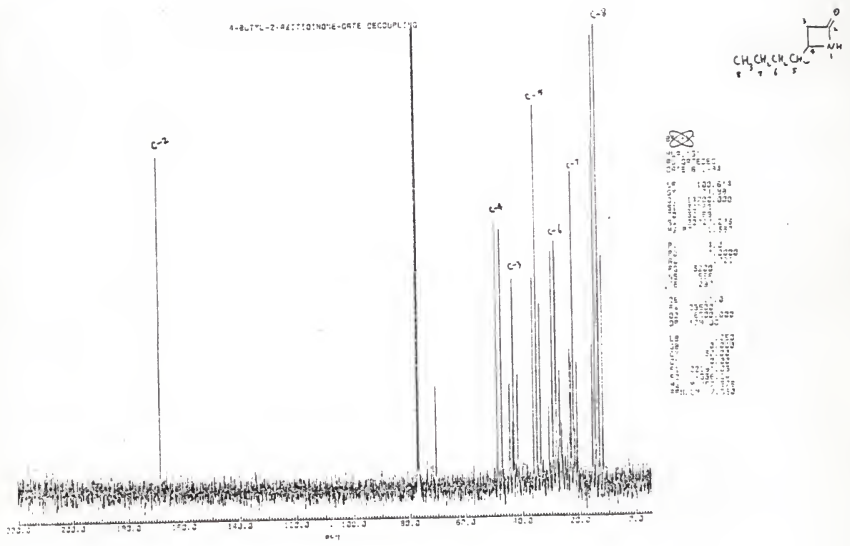




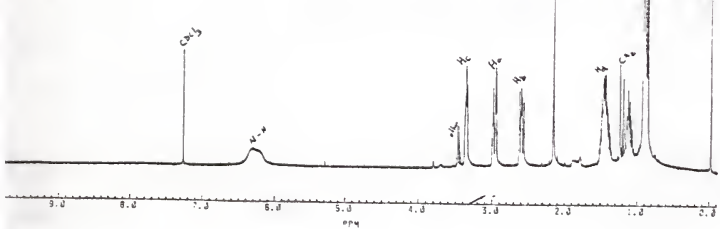

\section{8}

उ4: :2-3-94

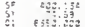

5 i 3 - 3

$\sum_{i, 71}$

年

is

药

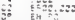

然

(1)

$\therefore$ ision 
IS C.NMR
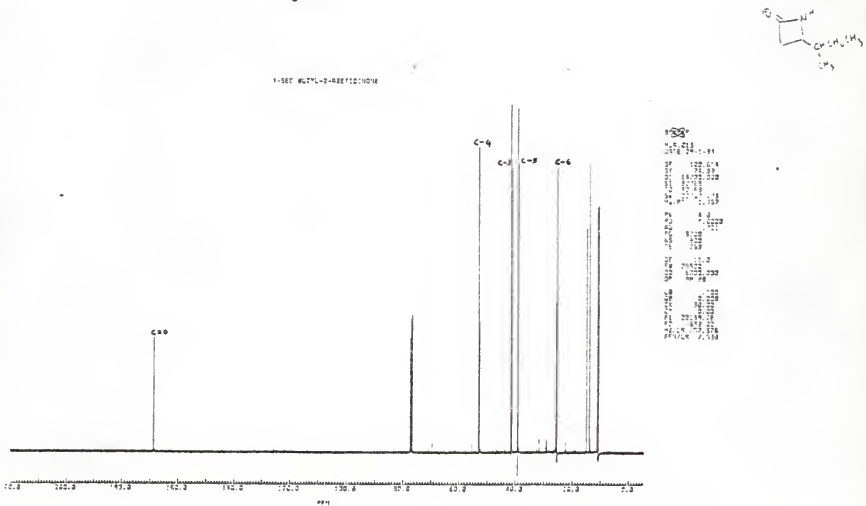
so

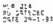

1ै 120

i1

at

㛭

谋

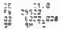

in

i. $=x^{4}$

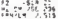
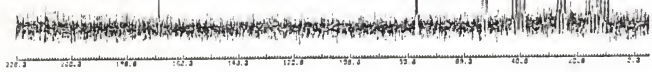
$A G V=I-006^{\circ}$

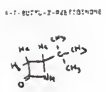

3.

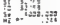

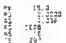

壁

4 ,

$43 y^{4}$

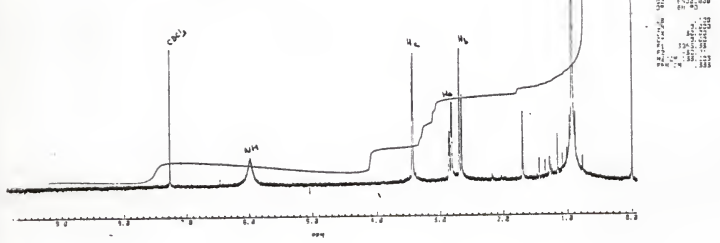




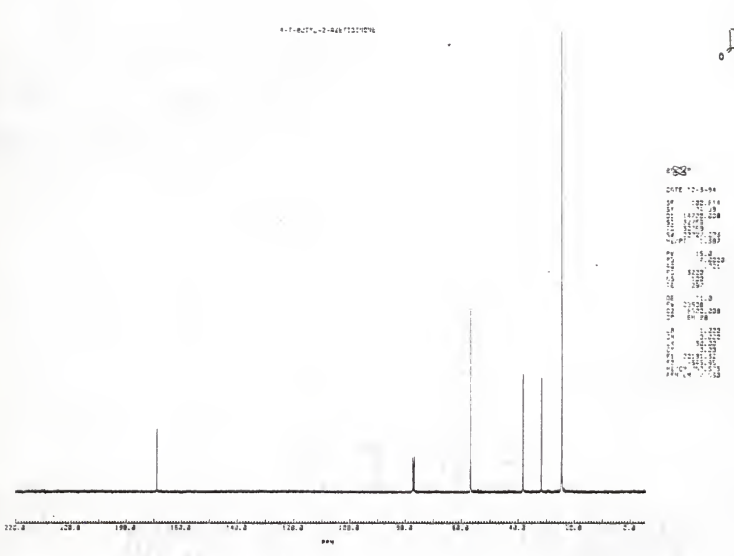


MGV $-i i-\cos$
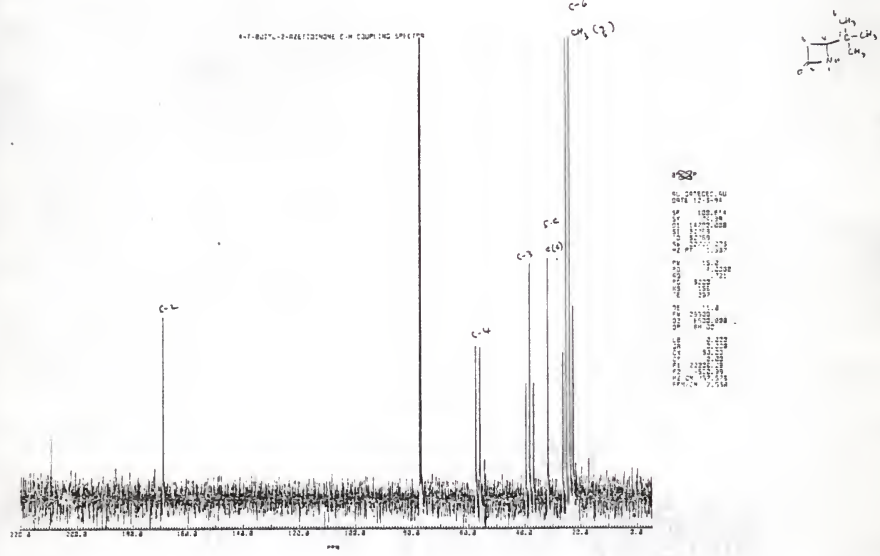

18

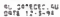

3)

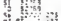

7.

整

诰

ㄴ.t.

m

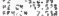


DH. J-261-3

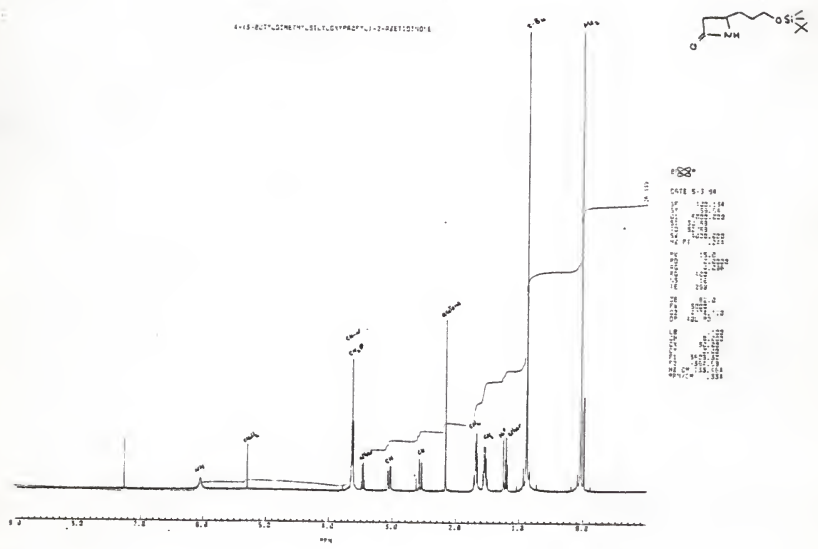




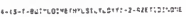
2.40

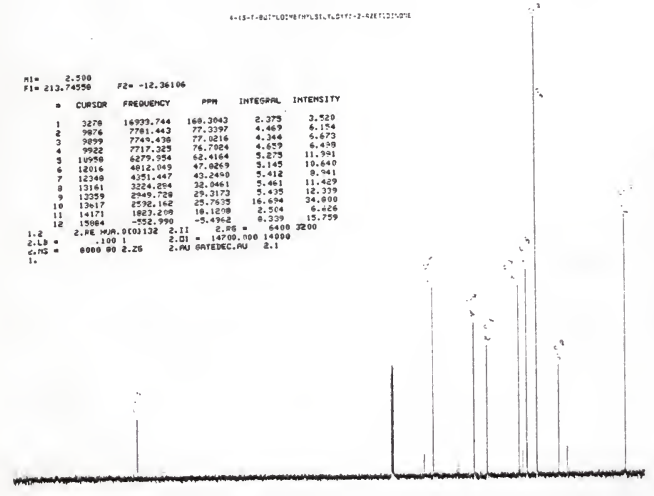

D. $=2.261-4$

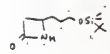

88

1:

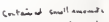

an'u $=0, c^{1}, \omega$

(b. wine) 


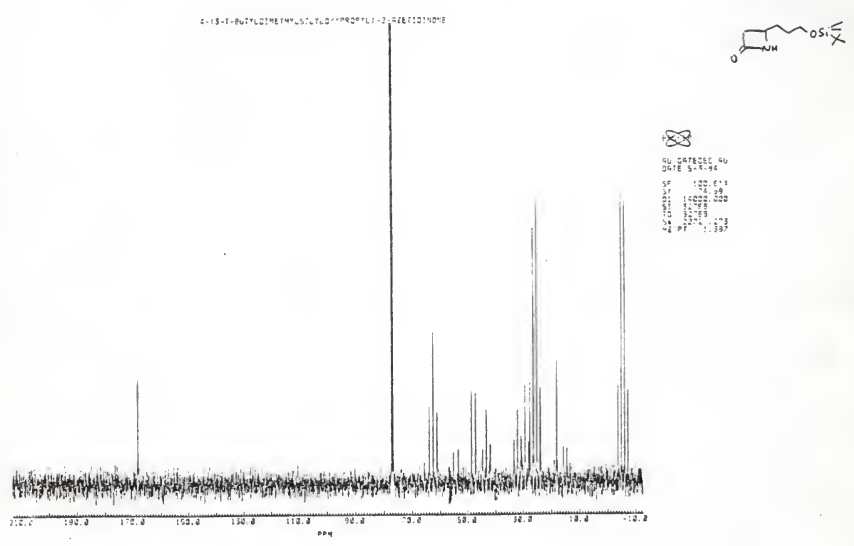




$$
\text { in }
$$




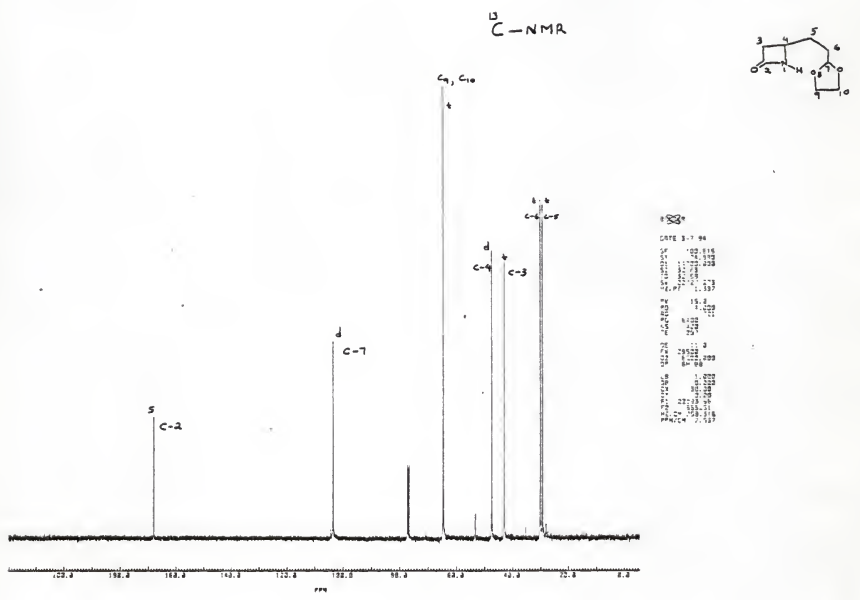



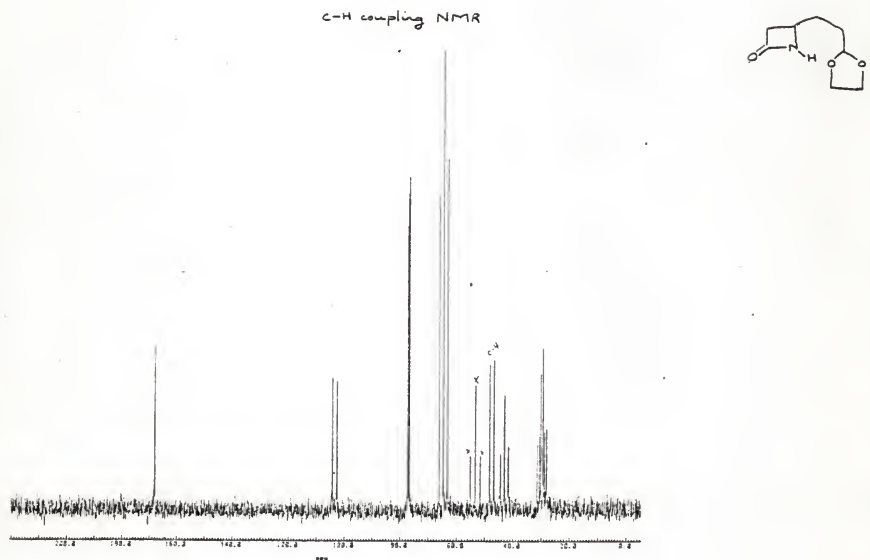


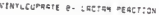

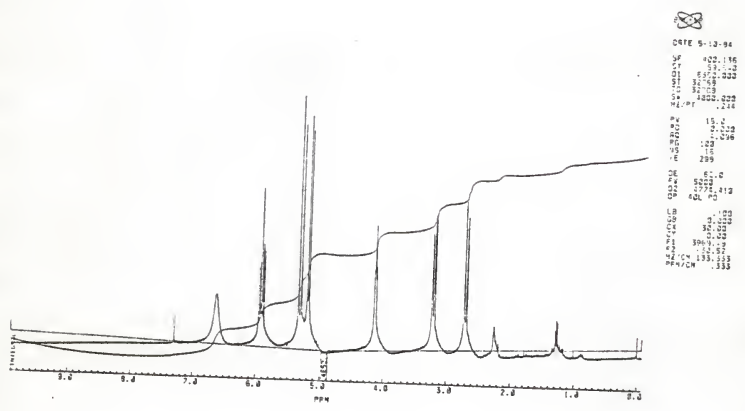


60

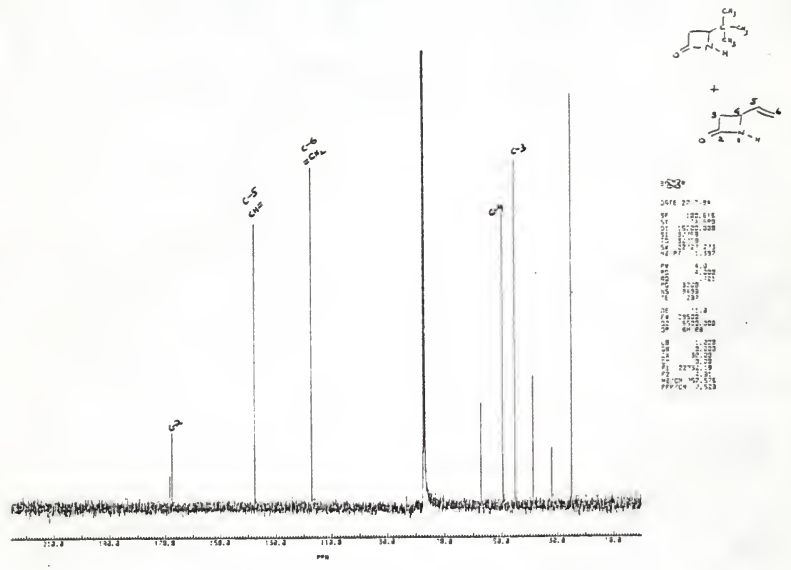




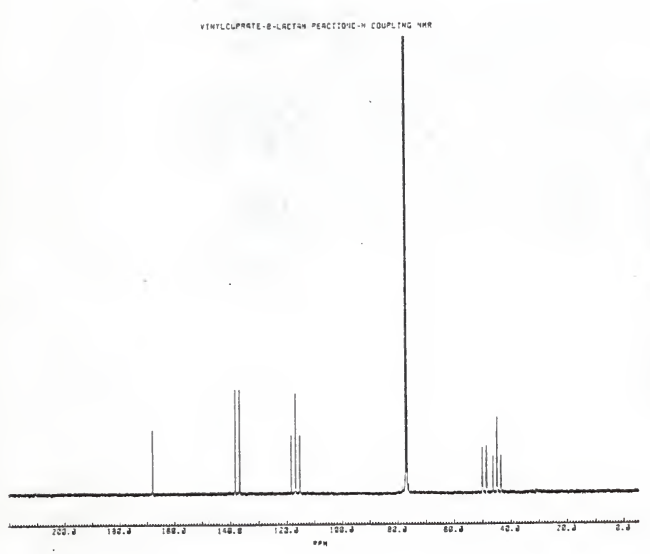

8

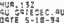

5\%. $129.8 \%$

13

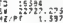

(1) $4: 43$

貿

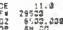

结 d.

4221375

4.

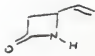




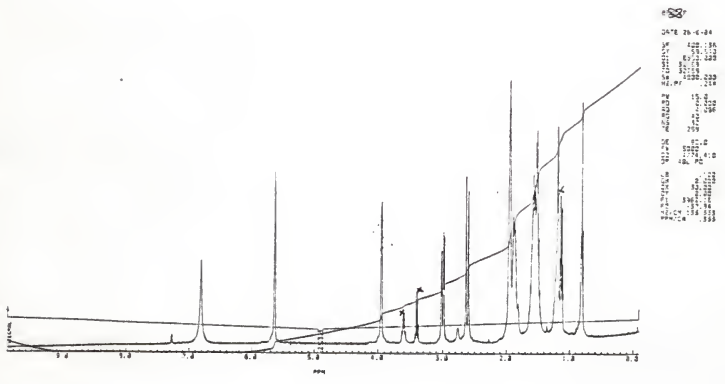




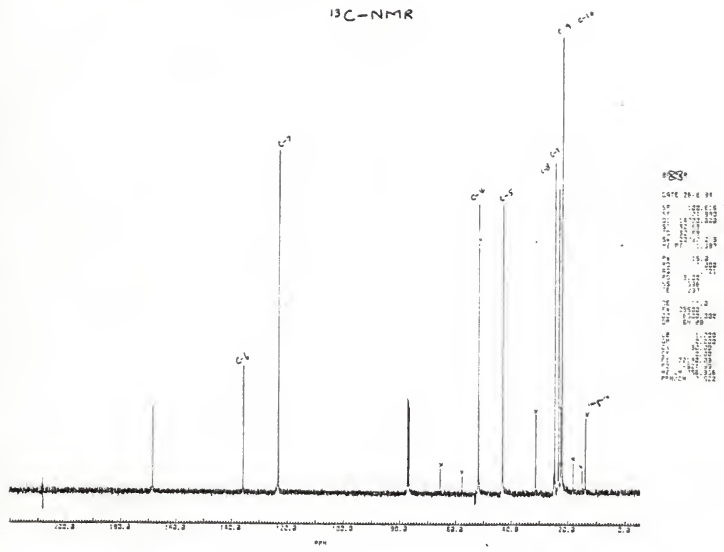




$$
C-H \text { coupling NMR of } A G V-I I-041^{\circ}
$$

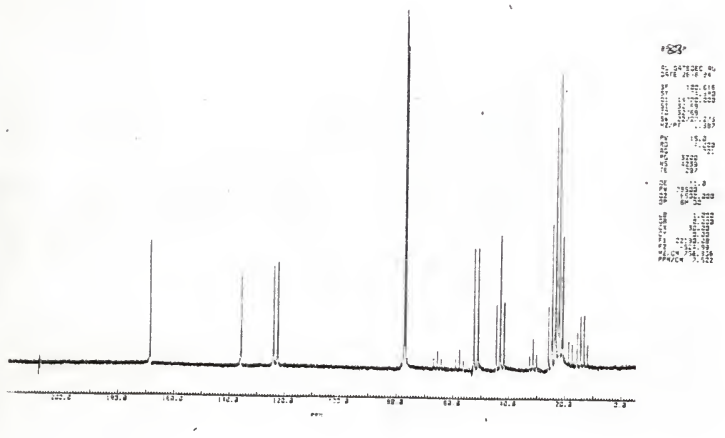




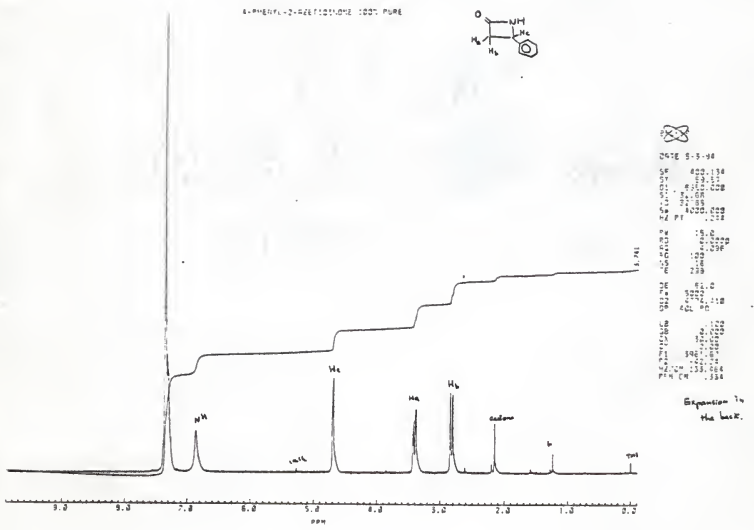




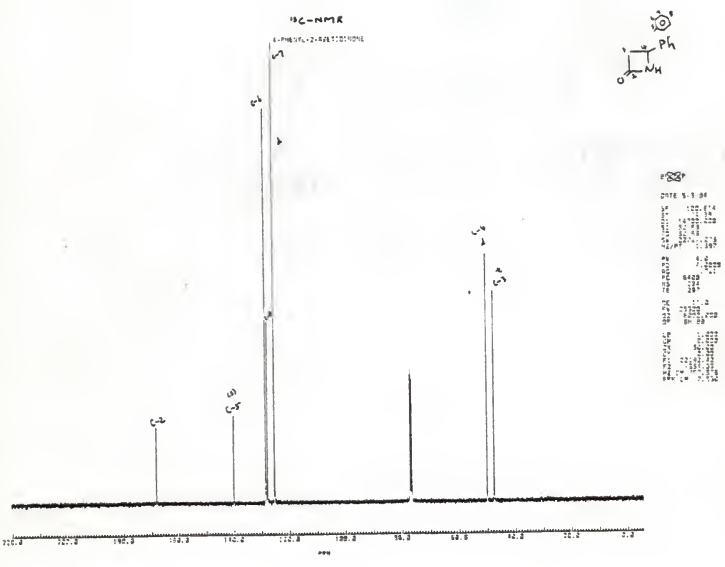




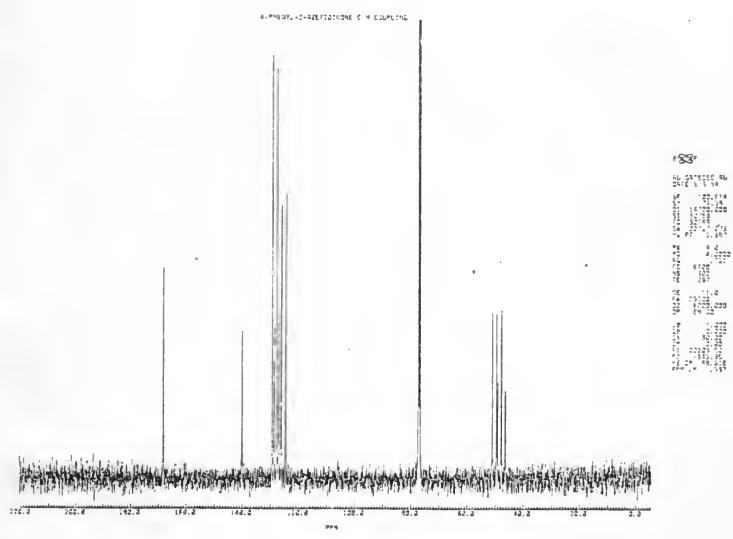




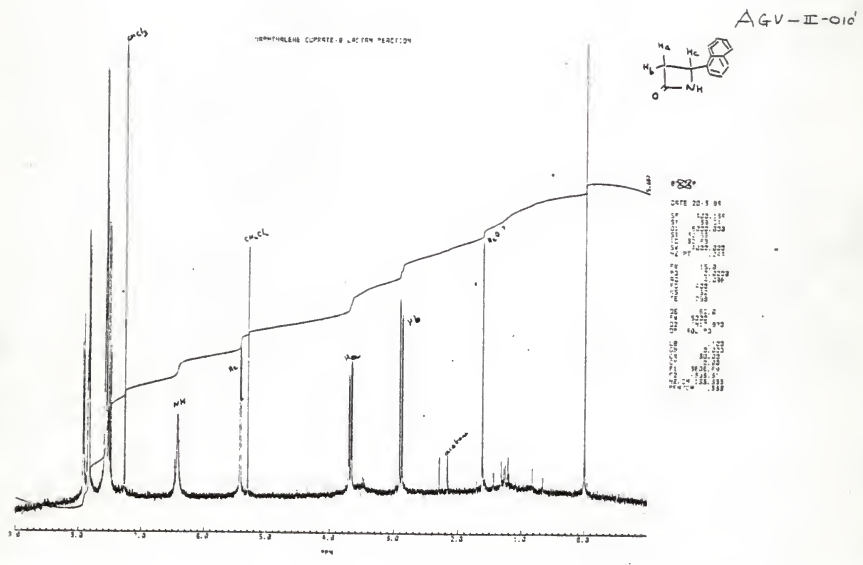




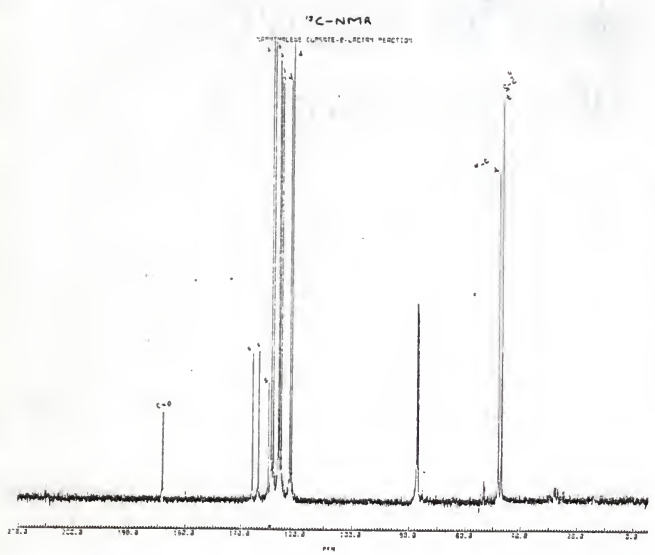

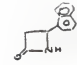

$A G V-I I-013 ;$
.88.

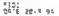

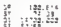

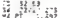

4. 5

然

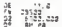

总

is 

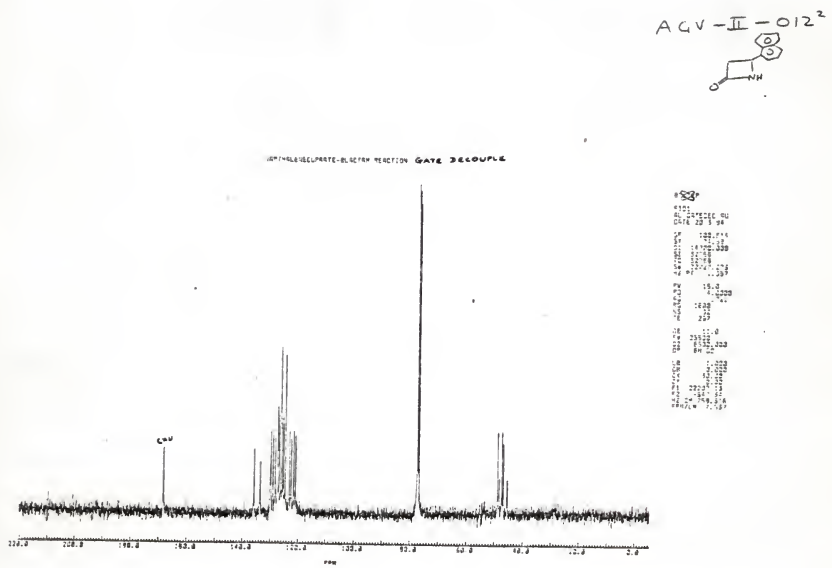

-8.

stit

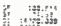

章 14.

然

势 :

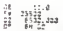

4 策

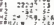

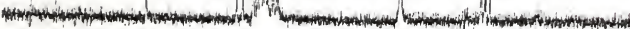




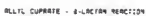
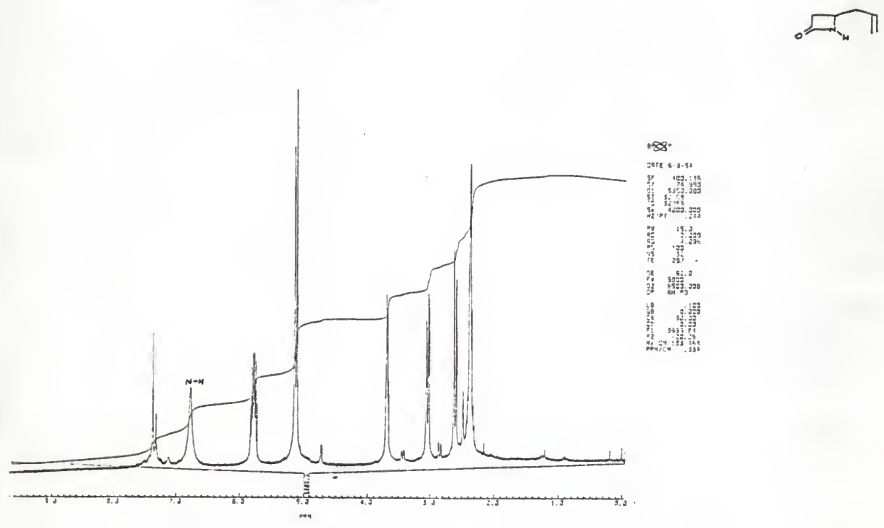


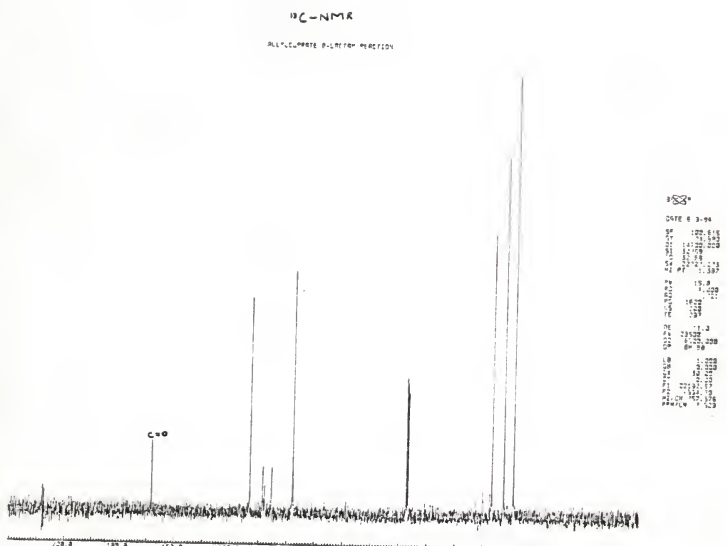




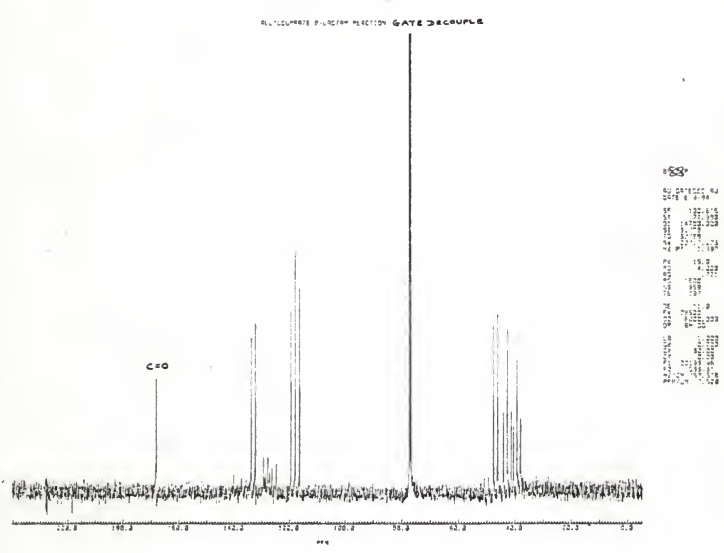




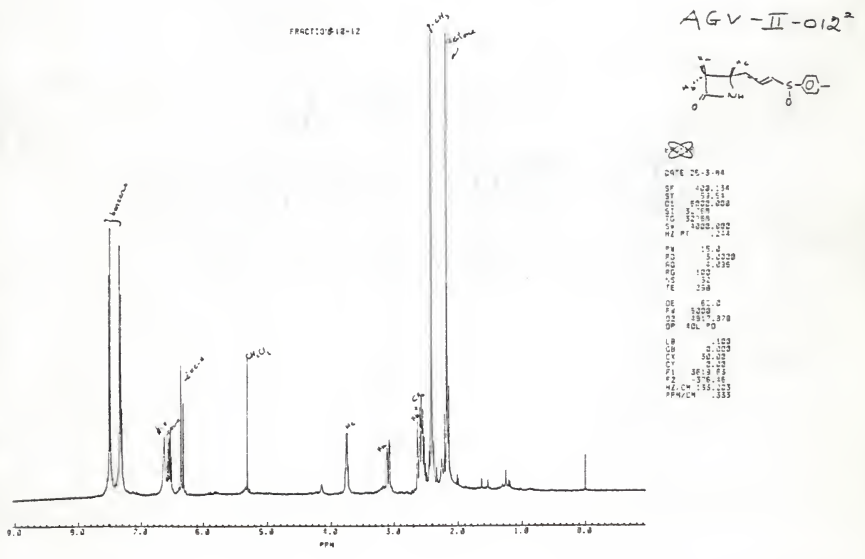




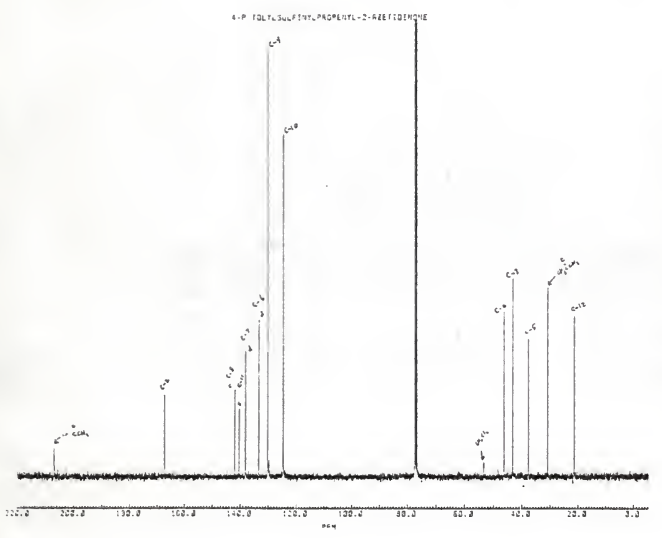

8

2476 25-5-94

की 15

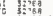

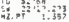

政

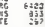

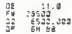

题

If 22 :

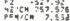

AGV - II - 0123

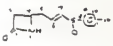

scolans

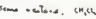

$\mathrm{CW}_{2}-\bar{i}-\mathrm{i}-\mathrm{cos}$

${ }_{216} \mathrm{C}_{24.3}$

insel, 


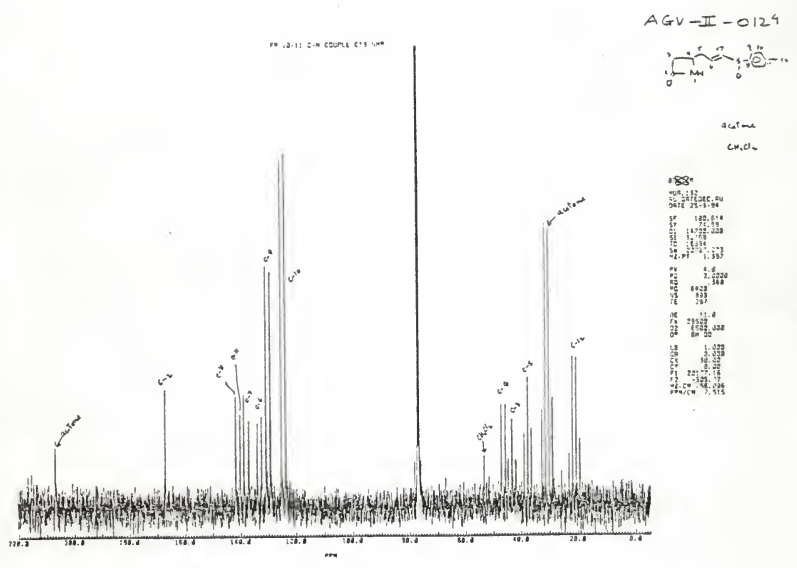




\section{ACKNOWLEDGEMENTS}

I wish to express ay appreciation and gratitude to my research advisor, Dr. Duy H. Hua, for his close zuldance and inspiring discussions throughout the course of this research work. I especially wish to thank my parents and my brother and sister without whose love and moral support I would have never been able to complete this work.

I am also grateful to the Department of Chemistry, Kansas State University, for the enancial support in the form of a teaching assistantship and Kansas State Bureau of General Research for support of this research. 


\title{
SYNTHESIS OF 4-SUBSTITUTED 2-AZETIDINONES
}

\author{
by \\ Akhilkumar Verma \\ M.S. - Bombay University; India
}

AN ABSTRACT OF A MASTER'S THESIS

submitted in partial fulfillment of the

requirements for the degree

MASTER OF SCIENCE

Department of Chemistry

KANSAS STATE UNIVERSITY

Manhattan, Kansas

1984 


\section{ABSTRACT}

4-Substituted 2-azetidinones can be obtained in excellent yields from the reactions of various cuprates with 4-acetoxy-2-azetidinone. When 4acetoxy-2-azetidinone was treated with one equivalent of the cuprates in ether: dimethylsulfide $(1: 1)$ at $-50^{\circ} \mathrm{C}$ to $-30^{\circ} \mathrm{C}$, only $20-30 \%$ of the corresponding 4-substituted 2-azetidinones were obtained. However when two equivalents of the cuprates were used, the yields were excellent (71-98\%). By this method we have been able to introduce alkyl, aryl, allyl and alkenyl groups at the 4-position of 2-azetidinones in excellent yields. 